\title{
35. MACROINVERTEBRATE PALEONTOLOGY, BIOCHRONOLOGY, AND PALEOENVIRONMENTS OF LOWER CRETACEOUS AND UPPER JURASSIC ROCKS, DEEP SEA DRILLING HOLE 511, EASTERN FALKLAND PLATEAU ${ }^{1}$
}

\author{
J. A. Jeletzky, Geological Survey of Canada, Ottawa, Ontario, Canada
}

\begin{abstract}
Macroinvertebrate fossils from Mesozoic beds of Hole 511, Leg 71, were extracted and studied. Albian clays and marls of Sections 511-50-1 to 511-57-1 lack neritic belemnites but contain shelf-break foraminifers and numerous coquinas of Aucellina radiatostriata, which thrived in this environment because mud was intermittently removed by strong currents. Sections 511-57-2 to 511-58-3 contain late Aptian Epicheloniceras, Aconeceras?, and Australiceras? but lack belemnites and neritic pelecypods. Their mudstones are anoxic outermost neritic or upper bathyal deposits. Lower Aptian and ?uppermost Barremian fine-grained, calcareous sandstones of Sections 511-58-4 to 511-60-5 contain belemnites and numerous shallow-water pteriid pelecypods including the diagnostic Aucellina ex aff. radiatostriata. These well-aerated, inner neritic deposits indicate a brief regression. Planktonic foraminifers indicate a Barremian to ?basal Aptian age for Sections 511-60-5 to 511-62-5. These petroliferous, perhaps bathyal mudstones almost lack macroinvertebrates but are rich in fish remains. They overlie unconformably lower upper to ?mid-upper Tithonian (=upper Kimmeridgian and perhaps slightly later) Sections 511-63-1 to 511-64-3. Uppermost Jurassic to Hauterivian rocks are absent, either because they were not deposited or perhaps because they were later eroded.

Petroliferous mudstones of Sections 511-63-1 to 511-64-3, below this unconformity, are mid-neritic deposits containing oxytomid pelecypods, buchiids, ostreids, belemnites (Hibolithes and Hastites? only), and ammonites. This fauna includes the diagnostic Virgatosphinctes ex aff. densistriatus-denseplicatus and Malayomaorica occidentalis $\mathrm{n}$. $\mathrm{sp}$.

Sections 511-64-4 to 511-67-3 contain late early Tithonian (=mid-Kimmeridgian) Belemnopsis spp. ex gr. uhligi and $M$. occidentalis n.sp. The lower part of these beds is a complex interbedding of fossiliferous sandy mudstones with pelecypod coquinas replete with oysters. These innermost neritic, lagoonal and estuarine beds record a major shoaling and freshening event.

The lowest Sections 511-67-4 to 511-70-5 contain early early Tithonian (=early Kimmeridgian) Jeletzkiella falklandensis and B. cf. keari, the presence of which apparently contradicts the Oxfordian age suggested by microfossils. These petroliferous mudstones are mid-neritic, partly anoxic deposits.
\end{abstract}

\section{INTRODUCTION}

Abundant and varied macroinvertebrate fossils were collected from Lithological Units 5 and 6 of Leg 71 Hole 511 , which was drilled within the basin province of the Falkland Plateau, southern Atlantic Ocean, at $51^{\circ}$ $00.28^{\prime} \mathrm{S} ; 46^{\circ} 58.30^{\prime} \mathrm{W}$. Hole 511 is situated about $10 \mathrm{~km}$ south of Site 330 (DSDP Leg 36), which has also yielded important Late Jurassic and Early Cretaceous macroinvertebrates (Jones and Plafker, 1977) (see Fig. 1).

This chapter summarizes the most important results obtained to date about the macroinvertebrate palaeontology, biochronology, and palaeoenvironment of the Lower Cretaceous and Jurassic beds of Hole 511. Upper Cretaceous beds did not yield any immediately diagnostic macroinvertebrates and will not be treated in this report, except for the beds adjoining the upper Lower Cretaceous beds. Because of publication deadlines, this study had to be restricted to the most diagnostic macroinvertebrates found. Index fossils utilized include the rare and poorly preserved ammonites, the most important oxytomid and buchiid pelecypods, and belemnites. The most important occurrences of these fossils are listed in Figure 2 and the best preserved representatives of their most important taxa are briefly described and

\footnotetext{
${ }^{1}$ Ludwig, W, J, and Krasheninnikov, V. A, et al., Init. Repts. DSDP, 71: Washington (U.S. Govt. Printing Office).
}

figured. The biochronologic and paleoenvironmental significance of these diagnostic invertebrates is discussed.

The remainder of these Late Jurassic and Cretaceous macroinvertebrate faunas of Hole 511 has not been studied in any detail. These fossils, mostly poorly to execrably preserved, consist of a considerable number of insufficiently understood oxytomid pelecypods which include at least one new genus, pelecypods other than the Oxytomidae, some gastropods, solitary corals, and generically indeterminate belemnites. The rich oxytomid fauna of the Aucellina ex aff. radiatostriata beds and the buchiid fauna of the Upper Jurassic beds will be the subject of a special study, as also will all specifically identifiable Lower Cretaceous and Upper Jurassic belemnites of Hole 511. All new taxa of these fossil groups listed informally in this report will be formally erected in those papers.

\section{BIOCHRONOLOGY}

The following biochronological subdivision of Cores 48 to 70 , Lithological Units 5 and 6 , is indicated by the macroinvertebrate fossils studied.

\section{Lower Upper Cretaceous}

Cores 47 and 48 of Unit 5 to a depth of 422.0 meters (Fig. 2) contain numerous but fragmentary and hence indeterminate remains of Inoceramus s.1., a few other indeterminate pelecypods, and, locally, a number of ge- 


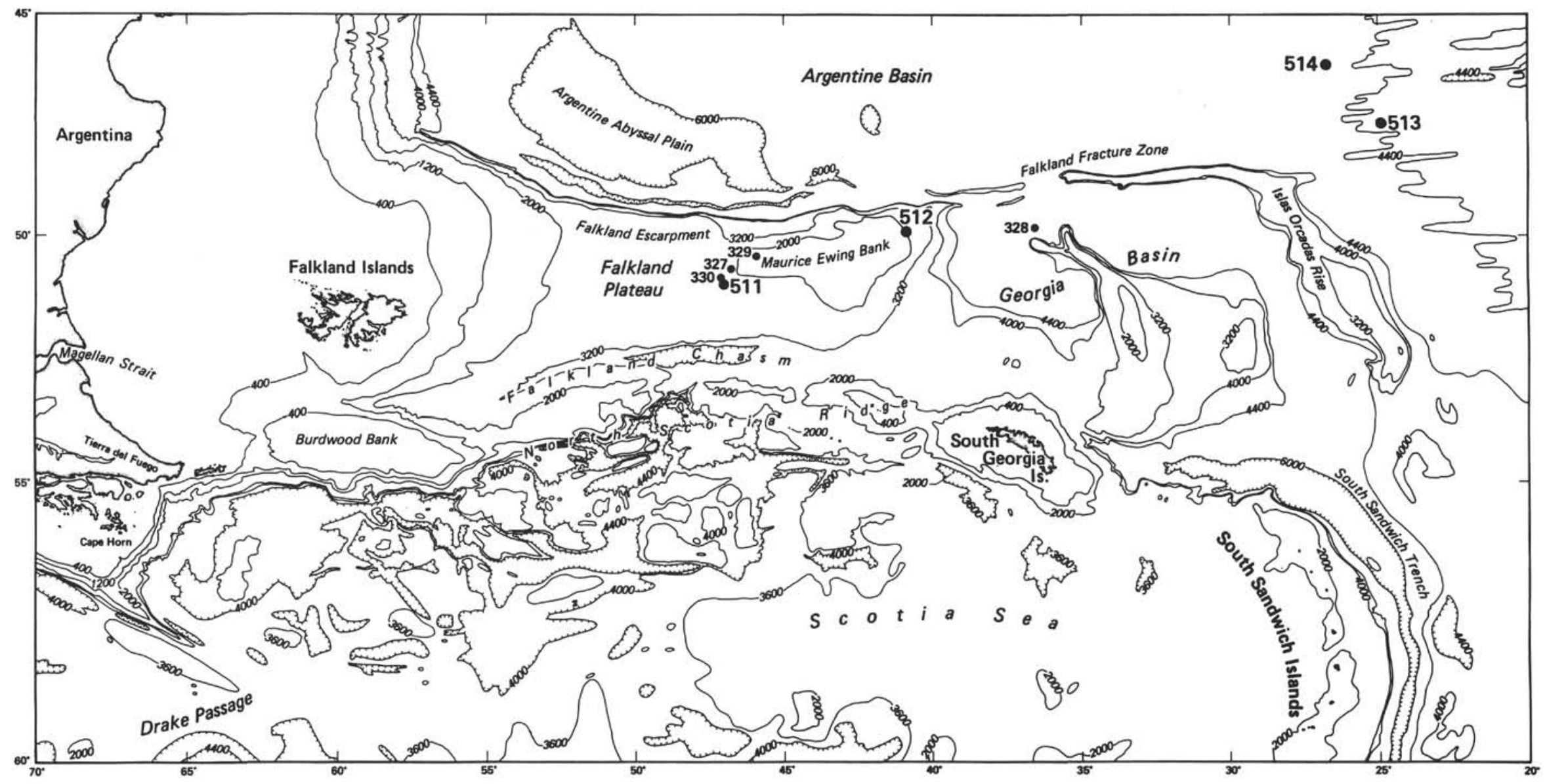

Figure 1. Leg 71 site locations. 


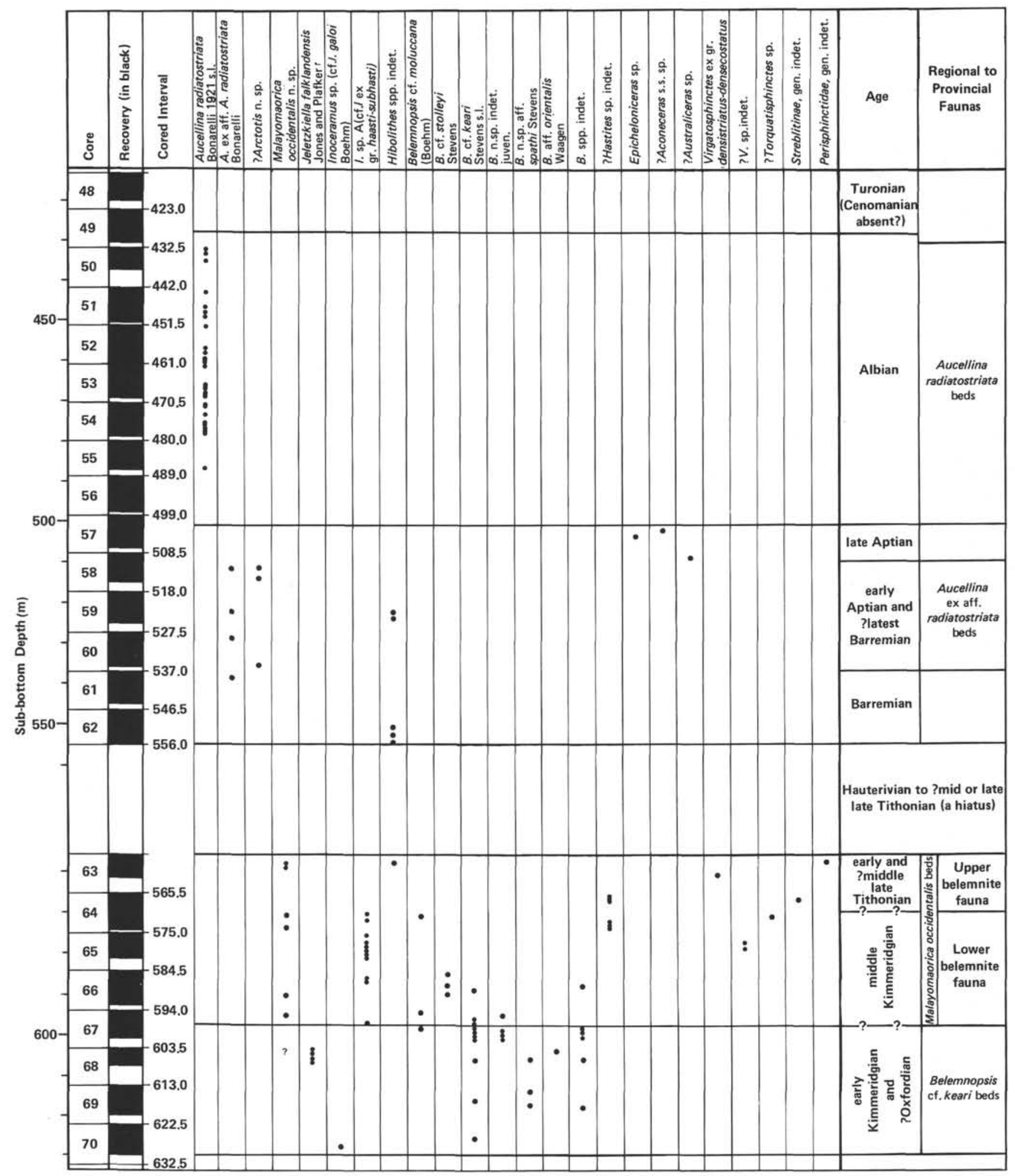

Figure 2. Macrofossil biochronology and stratigraphy of Upper Jurassic and Lower Cretaceous rocks of DSDP Hole 511.

nerically indeterminate solitary corals (evidently redeposited, in part at least). These cores cannot be dated by their macroinvertebrate content, beyond a tentative suggestion of a generally Late Cretaceous age that is based on the apparently Late Cretaceous appearance of the best preserved Inoceramus s.l. fragments. These cores have been assigned a Turonian age on the strength of their foraminiferal content (Krasheninnikov and Basov, this volume), but since they are beyond the scope of this report, they will not be discussed further.

Core 49 yielded no diagnostic macrofossils. However, Krasheninnikov and Basov (this volume) found rare spec- 
imens of Ticinella raynaudi in Sample 511-49-5, 120-122 $\mathrm{cm}$, which indicates a late Albian age up to that level of the core. The Albian sediments must end only a few $\mathrm{cm}$ higher in this core, according to Krasheninnikov and Basov (this volume), as Sample 511-49-5, 102-104 cm yielded very rare specimens of Praeglobigerina turbina$t a$, which suggests a late Cenomanian age. However, an early Turonian age cannot be ruled out for this sample, according to Krasheninnikov and Basov (this volume). The microfaunal data suggest the presence of a hiatus in the interval between these two foraminiferal faunas (Fig. 2).

\section{Albian Beds: Aucellina radiatostriata Beds}

Sections 511-50-1 to 511-55-5 (beginning at $442 \mathrm{~m}$ sub-bottom depth) and, presumably, Sections 511-55-6 to 511-57-1 (ending at $\sim 497 \mathrm{~m}$ sub-bottom depth) contain extremely numerous Aucellina radiatostriata Bonarelli, 1921 s.l. (Fig. 2). As here interpreted, this species includes all Albian and Aptian Aucellina forms previously described from the adjacent Patagonian Basin of the Argentinian mainland. Even $A$. andina Feruglio, 1937 is treated herein as a morphological variant of $A$. radiatostriata s.1. (compare Macellari, 1979, pp. 143172 , pls. I-III).

So interpreted, $A$. radiatostriata appears to range right through the Aptian and Albian stages of the Argentinian mainland (Macellari, 1979, p. 245). It appears to have a similar time range in adjacent Antarctic regions (Wilkens, 1947; Cox, 1953), New Zealand (Stevens and Speden, 1978, pp. 284-288, table IV, figs. 32-33; Stevens, 1978, Vol. II, pp. 352, 353, table 6.2), and Australia (Day, 1969, p. 161; Ludbrook, 1966, pp. 21, $22,155,156$; Ludbrook, 1978 , pp. 237-238). It is possible that the genus Aucellina ranges up into the Cenomanian rocks of the Southern Hemisphere, as it does in the Northern Hemisphere (Pompeckj, 1901; Pavlow, 1907). However, this has not yet been established anywhere in the Southern Hemisphere, to the best of my knowledge, and it does not appear to happen in Hole 511, where Core 49, which according to Krasheninnikov and Basov (this volume) contains late Albian and late Cenomanian (or ?early Turonian) foraminifer fauna, did not yield any Aucellina. The topmost representatives of $A$. radiatostriata were found in Core 50 (Fig. 2) and so are definitely Albian in age. An Aptian to Albian time range for $A$. radiatostriata may, however, be apparent rather than real, if there is a Cenomanian hiatus, which is strongly suggested by the absence of early to mid-Cenomanian foraminifers in Core 49.

Judging by the known time range of $A$. radiatostriata s.l. on the mainland of Argentina and in Antarctica, Sections 511-50-1 to 511-55-5 could be either Aptian, Albian, or both in age. However, they and the underlying poorly fossiliferous Sections 511-55-6 to 511-56-5 appear to be entirely Albian in age, because they occur, stratigraphically, above the reliably upper Aptian beds containing Epicheloniceras sp., Aconeceras? s.s. and an Albian foraminiferal fauna (Krasheninnikov and Basov, this volume) (see Fig. 3).
Sections 511-57-1 and 511-57-2, which did not yield any determinable macrofossils, separate the presumably Albian Sections 511-55-6 to 511-56-5 from the highest upper Aptian Section 511-57-3. However, they contain Albian foraminifers and so are placed in the earliest $\mathrm{Al}$ bian in this chapter (Figs. 2-3).

\section{Upper Aptian Beds}

Sections $511-57-3$ to $511-58-1$ inclusive contain rare and poorly preserved but nevertheless diagnostic cheloniceratid, aconeceratid, and ancyloceratid ammonites of Aptian affinities (Fig. 2).

The upper part of this interval (Samples 511-57-3, 50$51 \mathrm{~cm}, 511-57-4,73-75 \mathrm{~cm}, 511-57-5,2-3 \mathrm{~cm}$, and 511$57-5,23-71 \mathrm{~cm}$ ) are unreservedly assigned a late Aptian age. This is indicated, first of all, by the presence of Cheloniceras (Epicheloniceras) sp. (P1. 1, Fig. 7) in Sample 511-57-4, 65-66 cm. The genus Cheloniceras $\mathrm{Hy}$ att, 1903 and the subgenus Epicheloniceras Casey, 1954 occur almost worldwide in the low to mid-latitudinal belt. They are restricted to the upper Aptian throughout their geographic range, including South America (Wright in Arkell et al., 1957, p. L385; Casey, 1961).

The tentative identifications of Aconeceras? s.s. in Samples 511-57-3, 50-51 cm (Pl. 1, Fig. 1), 511-57-4, $73-75 \mathrm{~cm}, 511-57-5,2-3 \mathrm{~cm}$, and 511-57-5, $23 \mathrm{~cm}$ would, in itself be only suggestive of a late Barremian to early Albian age (Casey, 1954, pp. 270-272; Wright, in Arkell et al., 1957, p. L286). However, in combination with the presence of Cheloniceras (Epicheloniceras) sp. in Sample 511-57-4, 65-66 cm and of a tentatively identified late or perhaps late early Aptian Australiceras? sp. closely below the sample with Aconeceras? s.s., there seems little doubt about its late Aptian age.

Sample 511-58-1, 137-138 cm and, tentatively, Samples 511-58-1, 70-71 $\mathrm{cm}$ and 511-58-1, 98-99 $\mathrm{cm}$ above it can only be assigned a late or ?late early Aptian age because of a solitary ancyloceratid fragment (Pl. 1, Fig. 2), questionably placed in the genus Australiceras Whitehouse, 1926 (pp. 208, 209). Although Australiceras has been considered to be principally a late Aptian genus (Casey 1960-66, pt. 1, pp. 44, 45; Day, 1974, pp. 9; and Klinger and Kennedy, 1977, pp. 287, 291), it includes the late early Aptian species group of $A$. gigas. However, the bed in 511-58-1, 137-138 that contains this fragment is stratigraphically close below the bed containing Epicheloniceras sp., which suggests an early late Aptian age.

The $A$ ? sp. of Hole 511 does not seem to differ materially from the similarly large fragment of $A$. irregulare (Tenison-Wood) figured by Day (1974, pl. 6, fig. 2c) if one mentally restores its three-dimensional cross-section. However, it could possibly belong to the Barremian Crioceratites (Emericiceras) ex gr. alpinum (d'Orbigny), the early whorls of which may have a similarly coarse and pronouncedly nodose sculpture. In my opinion, a late Barremian date for the core is improbable. The genus Australiceras is widespread in the Southern Hemisphere, presumably including the adjacent Patagonian Basin of the Argentinian mainland (Klinger and 
Kennedy, 1977, p. 291). Crioceratites (Emericiceras) ex gr. alpinum appears, in contrast, to be restricted to the Northern Hemisphere (Wright in Arkell et al., 1957, p. L208). An even more important argument indicating a late Aptian age for the bed in 511-58-1, 137-138 and the superjacent unfossiliferous beds is the presence of the lower Aptian and perhaps uppermost Barremian beds bearing Aucellina ex aff. radiatostriata stratigraphically below them.

\section{Lower Aptian and ?uppermost Barremian Beds: Aucellina ex aff. radiatostriata Beds}

The interval from Section 511-58-4 to 511-62-5, 70 $\mathrm{cm}$ inclusive contains readily identifiable Aucellina ex aff. radiatostriata (see Pl. 3, Fig. 12) in Samples 511-59$3,134-138 \mathrm{~cm}, 511-58-4,137-139 \mathrm{~cm}$, and 511-60-1, 86-91 cm. Other pteriid pelecypods of this fauna include somewhat peculiar, Meleagrinella-like forms (e.g, P1. 3, Figs. 5, 9-10) found in Samples 511-59-4, 13-14 $\mathrm{cm}, 511-59-4,98-99 \mathrm{~cm}$ and 511-60-2, 53-58 cm levels and at least one new pteriid genus to be described and named elsewhere. Furthermore, this fauna was found to include forms either congeneric with or closely related to the Arctic genus Arctotis Bodylevsky, 1960 (Pl. 1, Figs. 11, 15; Pl. 3, Figs. 2, 16). Yet other oxytomids of this fauna may or may not represent a new species of Maccoyella Etheridge, 1892 (see Cox, 1969, p. N346, fig. C70-4). The study of these interesting oxytomids is under way and their definitive identifications and descriptions will be published elsewhere at a later date. Except for a few fragments of totally indeterminate, thinshelled pelecypods, very rare fragments of Dentalium (s.1.) sp. indet., and relatively rare belemnites belonging to the genus Hibolithes sp. indet. A (Pl. 2, Fig. 6), the rather rich macroinvertebrate fauna of this interval consists exclusively of variegated oxytomids.

Of the most prominent, already identified oxytomids, those believed to represent the unnamed new genus and species range from Sample 511-58-4,CC $(12-24 \mathrm{~cm})$ down to Sample 511-60-2, 53-58 cm. ?Arctotis n. spp., which superficially resembles $A$. intermedia Bodylevsky, 1960 (Pl. 1, Figs. 11, 15; Pl. 3, Figs. 2, 16), ranges from Sample 511-60-1, 35-42 cm down almost to the assigned base of the unit (i.e., to Sample 511-60-5, 30-32 cm). No definitively identifiable representatives of Aucellina ex aff. radiatostriata have been yet found below Sample 511-60-1, 86-91 cm, but some suggestive fragments have been seen in Sample 511-60-3, 59-61 cm. Therefore, the whole interval down to Sample 511-60-5, $70 \mathrm{~cm}$, where the macrofossils (including all oxytomid forms) disappear, is treated tentatively as a biochronological unit characterized by $A$. ex aff. radiatostriata, and is designated the $A$. ex aff. radiatostriata beds (Figs. 2-3). The presence of a uniform Barremian-Aptian assemblage of planktonic foraminifers in Cores 511-58 to 511-62 inclusive (Krasheninnikov and Basov, this volume) supports this conclusion.

The common presence of $A$. ex aff. radiatostriata in the interval from Section 511-58-4 to 511-60-5, $70 \mathrm{~cm}$ indicates that these beds are no older than the upper Barremian Stage. Furthermore, this unit may well be still Aptian in its entirety. A possible late Barremian age for the $A$. ex aff. radiatostriata fauna of Hole 511 is suggested only because of the common presence of $A$. ex gr. aptiensis-caucasica in the reliably dated upper Barremian beds of Arctic Canada (Jeletzky, 1964, pp. 5867, pls. XV-XVIII, table I; 1968, p. 12). Aucellina appear to be equally common in the upper Barremian rocks of northeastern Siberia (i.e., in the Anadyr-Koriak Region; see Verestchagin et al., 1965, pp. 29-30, pl. 13, figs. $1-3$; pl. 14, figs. $1-9$; pl. 15, figs. 1-2; Verestchagin, 1977, p. 161), but the late Barremian age assigned these deposits has been questioned (e.g., Terekhova, 1972, p. 203). The age of the oldest known Aucellina forms of Arctic Canada is not necessarily relevant for dating the $A$. ex aff. radiatostriata fauna of Hole 511, because the two occur on almost the opposite sides of the globe, in different faunal realms. As far as I know, no Aucellina have yet been recorded from the pre-Aptian rocks of any region of the Southern Hemisphere (i.e., within the Austral or Antiboreal faunal realm). Therefore, and because the $A$. ex aff. radiatostriata beds are overlain directly by rocks that are either entirely or at least largely upper Aptian, these beds are provisionally assigned to the lower Aptian Stage in their entirety, with the proviso that they may possibly include some undifferentiated upper Barremian beds.

\section{Barremian Beds devoid of Diagnostic Macroinvertebrates}

The interval from Sample 511-60-5, $70 \mathrm{~cm}$ to the bottom of Core 511-62 did not yield any diagnostic macroinvertebrates. These beds are, however, largely or entirely Barremian in age because they immediately underlie the lower Aptian and ?uppermost Barremian beds and carry the same Barremian-Aptian planktonic foraminiferal fauna as the latter beds. According to Krasheninnikov et al. (this volume), this foraminiferal fauna persists downward into Core 62 and so dates the whole unit including the lower part of that core, which is included on other grounds (see next section).

\section{Late Tithonian to Hauterivian Hiatus and Unconformity}

The Barremian beds devoid of diagnostic macroinvertebrates are inferred to be separated from the underlying lower upper Tithonian to mid-Kimmeridgian beds by a prolonged hiatus and unconformity because of an extremely thin rock interval separating them (Fig. 2). However, neither an abrupt lithological boundary nor a conglomeratic interbed was observed anywhere within the core interval that separates the lowermost occurrence of the Barremian-Aptian foraminiferal fauna in in Core 511-62 from the uppermost fragment of a presumably Tithonian perisphinctid ammonite (Pl. 1, Fig. 3) found in Sample 511-63-1, 82-84 cm, and the unconformable contact between these two units is presumably situated within the uncored interval that separates Cores 62 and 63 . The presence of a prominent seismic reflector at $4.15 \mathrm{~s}$ (560 m BSF) (Ludwig, this volume) agrees well with this conclusion.

The macro- and microfossil evidence that is presented elsewhere in this chapter indicated that this hiatus embraces the bulk of the Neocomian (i.e., the Berriasian to 
Hauterivian) and the uppermost Jurassic (i.e., upper and possibly middle upper Tithonian). Sediment may not have been deposited because the area underwent a prolonged uplift above sea level; alternatively it may have been eroded after deposition, during or after a shortlived epeirogenic or orogenic phase in the late $\mathrm{Hau}$ terivian or earliest Barremian. In my opinion neither extremely slow sedimentation (i.e., a sediment-starved regime) nor submarine erosion can account for the absence of at least three standard stages in Hole 511.

\section{Lower Upper Tithonian to Middle Kimmeridgian Beds: Malayomaorica occidentalis Beds}

Study of ammonites, belemnites, and buchiid pelecypods in Sections 511-63-1 to 511-67-3 inclusive (Unit 6) indicates an early and possibly middle late Tithonian to mid-Kimmeridgian age. Neither upper upper Tithonian nor, apparently, the middle upper Tithonian rocks form part of this unit because of the macrofaunal evidence.

\section{Ammonite Fauna}

The perisphinctid ammonite found in Sample 511-633, 49-50 cm (Pl. 1, Fig. 9) is a Virgatosphinctes of the densistriatus-denseplicatus species group (see Indans, 1954, p. 101, for further details). This Virgatosphinctes species group characterizes the uppermost part of the lower upper Tithonian rocks (approximately, the upper Kimmeridgian of older usage) of the Argentinian mainland (i.e., the $V$. mendozanus Zone; see Leanza, 1980, pp. 15,16 for further details) and only questionably ascends into the middle upper Tithonian there and elsewhere.

The fragment of a perisphinctid ammonite found in Sample 511-63-1, 82-84 cm (Pl. 1, Fig. 3) only 82 to 84 $\mathrm{cm}$ stratigraphically below the top of the unit (Fig. 2), is generically indeterminate but seems to represent the same Torquatisphinctes-like morphological type as the better preserved fragment found farther down in Sample 511-64-4, 16-17 cm (Pl. 1, Fig. 5). Therefore, there does not seem to be any reason to suggest a late late Tithonian or Berriasian age for these topmost beds of the unit.

Two other virgatosphinctid ammonite fragments found in Samples 511-65-2, 40-41 cm and 511-65-2, 55$56 \mathrm{~cm}$ appear to be questionably referable to Virgatosphinctes but are too poorly preserved to be definitively identified generically.

A fragment of an oppeliid ammonite apparently referable to the Late Jurassic representative of the subfamily Streblitinae Spath, 1925 (see Arkell, in Arkell et al., 1957, p. 283) and found in Sample 511-64-1, 94-98 $\mathrm{cm}$ is also generically indeterminate and so does not provide any closer age determination. This specimen became so densely overgrown by molds that grew on it following its original identification that it was impossible to photograph.

Finally, a fragment of a perisphinctid ammonite found in Sample 511-64-4, 16-17 cm appears to be questionably referable to the genus Torquatisphinctes Spath, 1924 (Pl. 1, Fig. 5). This is suggested by distinct forward inclination of its biplicate ribs combined with the absence of any weakening of secondaries on the venter and the presence of some simple ribs between biplicate ones. Provided this tentative identification is correct, this ?Torquatisphinctes $\mathrm{sp}$. is suggestive of the early or midKimmeridgian to ?early late Tithonian age of the level (Arkell, 1957, in Arkell et al., 1957, p. 329).

\section{Malayomaorica Fauna}

The mid-early Tithonian (=mid-early Kimmeridgian) buchiid Malayomaorica Jeletzky, 1963 appears to range right through the unit and to be diagnostic of it. This pelecypod was found in Samples 511-63-1, 146-147 cm (Pl. 1, Fig. 13); 511-63-2, 3-4 cm; 511-64-5, 55-56 $\mathrm{cm}$; 511-65-3, 15-19 cm (Pl. 1, Fig. 8); 511-66-6, 6-8 $\mathrm{cm}$, and 511-67-2, 65-67 cm. It is unknown in the overlying and underlying units, except for the doubtful presence of a fragment of the right valve in Sample 511-682, 4-6 cm in the underlying lower Kimmeridgian and ?Oxfordian unit. The Malayomaorica specimens of Hole 511 are assigned to a new species, named $M$. occidentalis $\mathrm{n}$. sp, which is described in the Appendix to this chapter and is considered to be conspecific with $M$. cf. M. malayomaorica of Jones and Plafker (1977, p. 847, pl. 2, figs. 8, 10-11, 16-18), found at an apparently comparable stratigraphic level at the adjacent DSDP Site 330. Because of the apparent restriction of $M$. occidentalis $\mathrm{n}$. $\mathrm{sp}$. to the lower upper Tithonian to middle Kimmeridgian unit in Hole 511, this unit is designated as the $M$. occidentalis beds (Figs. 2-3).

According to the data previously available, the genus Malayomaorica, which previously has been considered to include only $M$. malayomaorica (Krumbeck, 1923), appears to be restricted to middle Kimmeridgian rocks (i.e., to the upper part of the regional Heterian and the lower part of the regional Ohauan stages) in New Zealand, where its time range is reasonably well known (Stevens, 1978, vol. 1, pp. 224, 225, table 4.11). These Malayomaorica-bearing beds approximately correspond to the mid-Kimmeridgian (i.e., approximately mid-Tithonian) of Bavaria and Silesia, because of the occurrence of a Kossmatia fauna (Arkell, 1956, pp. 110, 111, table 9; Stevens, 1978, vol. 1, p. 226, table 4.11). Malayomaorica is not recorded as ranging up into the lower upper Tithonian Puaroan Stage of New Zealand that is characterized by the presence of Aulacosphinctoides brownei (Marshall), Buchia? (presumably a new, still unnamed buchiid genus) plicata (Zittel), and " $\mathrm{Bu}$ chia"' aff. misolica (Krumbeck) (see Stevens, 1978, vol. 1 , pp. 224, 225, table 4.11).

The less definitively dated Indonesian occurrences of $M$. malayomaorica appear to be of the same mid-Kimmeridgian age as their New Zealand counterpart. This is suggested, in particular, by a near total identity of the Indonesian and New Zealand inocerami and belemnites associated with $M$. malayomaorica. In this region also $M$. malayomaorica is not recorded as ranging up into the so called "Aucella sandstone" that contains Buchia? subspitiensis, B.? motolensis, B.? subpallasi ${ }^{2}$ and ' $B$."'

\footnotetext{
${ }^{2}$ Since this was written, Zakharov (1981) has erected the genus Australobuchia for Buchia plicata (Zittel, 1864) (the type species) and other Buchia-like pelecypods of the IndoPacific region. B.? subspitiensis, B.? motolensis, and B. subpallasi appear to be referable to Australobuchia.
} 
misolica. The "Aucella sandstone" was correctly dated as a "lower Tithonian" (=lower upper Tithonian of this chapter) deposit by Stevens (1965a, pp. 138-140, table 13) and I correlate it with the Puaroan Regional Stage of New Zealand.

The apparent restriction of the genus Malayomaorica to the mid-Kimmeridgian rocks of New Zealand and Indonesia reflected its interpretation by other authors as a monotypic genus restricted to $M$. malayomaorica. This is an error, in my opinion; I have already pointed out (Jeletzky, 1963, p. 159) that the lower upper Tithonian "B." misolica Krumbeck, 1934 and " $B$." aff. misolica occurring in the Puaroan Stage of New Zealand are species of Malayomaorica. Therefore, the time range of the genus Malayomaorica in the Indo-Pacific region is accepted as approximately equivalent to that of $M$. occidentalis in Hole 511.

$M$. misolica and $M$. aff. misolica are considerably more strongly sculptured than $M$. malayomaorica. Their sculpture is, in particular, much more pronouncedly and coarsely reticulated. These Malayomaorica species cannot be confused with $M$. occidentalis n.sp., which lacks the radial ornament and the reticulation.

Because of these considerations, the upper part of the lower upper Tithonian to middle Kimmeridgian unit where $M$. occidentalis n.sp. is associated with Virgatosphinctes ex gr. densistriatus-denseplicatus (e.g., Samples $511-63-2,3-4 \mathrm{~cm}$ and $511-63-1,146-147 \mathrm{~cm}$ ) is correlative with the Puaroan Regional Stage and the "Aucella sandstone" of the Indo-Pacific region and does not range down into the lower Kimmeridgian.

\section{Belemnite Faunas}

There are two distinctive belemnite faunas in the lower upper Tithonian to middle Kimmeridgian beds.

\section{Upper Belemnite Fauna}

The rare and poorly preserved belemnites of the upper part of the lower upper Tithonian to middle Kimmeridgian unit confined between Samples 511-63-1, 70 $\mathrm{cm}$ and 511-64-3, 146-147 $\mathrm{cm}$ appear to resemble those of the overlying Barremian to lower Aptian beds but to be rather unlike those of the underlying middle Kimmeridgian part of the same unit. The fragment found in Sample 511-63-1, 146-147 $\mathrm{cm}$ is a Hibolithes s.s. that differs only specifically from the Hibolithes (s.s.) sp. indet. A of the overlying lower Aptian and ?uppermost Barremian unit (i.e., in Sample 511-59-4, 67-76 cm; see Pl. 2, Fig. 6) and from Hibolithes (s.s.) sp. indet. B of the Barremian unit (Pl. 2, Figs. 11-12). This Hibolithes sp. indet. cannot be compared with any of the previously described species I am familiar with.

Belemnite fragments found in Samples 511-64-1, 36$37 \mathrm{~cm}$ and 511-64-2, 131-132 $\mathrm{cm}$ are fragments of the stem (i.e., middle part of the postalveolar part of the guard) devoid of either medioventral or mediodorsal canals. Therefore, and because of the presence of what appears to be a slight medioventral furrow (not canal!), they may possibly belong to Hastites Mayer-Eymar, 1883 but cannot be definitively identified generically. The composition of this belemnite fauna is compatible with the early late and (?)mid-late Tithonian age indicated for these beds by their ammonite and Malayomaorica fauna. The genus Hibolithes s.s. is known to range down into the Kimmeridgian and upper Tithonian beds and to be quite common there in many regions of the Tethyan faunal realm (compare Stevens, 1965a). The genus Hastites is known to range up into the Kimmeridgian and upper Tithonian beds of the Tethyan Realm (Stevens, 1965a, p. 171, and Jeletzky, unpublished data). Because it occurs immediately above the lower belemnite fauna of the unit, which represents the early phase of the so called Belemnopsis uhligi complex (see later), this Hibolithes-?Hastites assemblage appears to correspond to the Hibolithes compressus complex of Misol (Stevens, 1965a, p. 139, table 13) and the $H$. minor fauna of New Zealand (Stevens, 1965a, p. 153).

\section{Lower Belemnite Fauna}

The rather common belemnites occurring in the lower part of the unit between Samples 511-64-3, 147-148 cm and the assigned base of the unit in Sample 511-67-3, $150 \mathrm{~cm}$ mostly belong to Belemnopsis spp. No Hibolithes s.s. and only a few Hastites-like belemnites were seen in this fauna, which is closely allied to the $B$. cf. keari fauna of the lower Kimmeridgian and ?Oxfordian unit that extends to Sample 511-70-3, 84-85 cm.

The invariably fragmentary Belemnopsis spp. of the lower belemnite fauna (mostly represented either by parts of the stem region or by the apical region only) differ from Hibolithes s.s. in that the guard is only slightly fusiform to subcylindrical in shape (sometimes even distinctly contracting adapically; e.g., Pl. 2, Fig. 4), and is combined with a wide and deep medioventral canal extending almost to the apex. This canal differentiates these Belemnopsis spp. from the European representatives of the genus and refers them to the so-called $B$. uhligi complex that is particularly characteristic of the early to mid-Tithonian (=early to mid-Kimmeridgian) of New Zealand, Indonesia, and the Himalayan region of the Indo-Pacific Province of the Tethyan faunal realm (Stevens, 1965a, pp. 170-173, 205-207). As Stevens noted, this uhligi complex may locally range down into the Oxfordian and up into the lower to middle upper Tithonian beds. Furthermore, it may locally include facies characterized by a considerable admixture of $\mathrm{Hi}$ bolithes spp. or considerable zones where Hibolithes spp. predominate. However, the principal early to midKimmeridgian phase of the uhligi complex is usually easily recognizable because of its specific composition and the presence of Malayomaorica malayomaorica and Inoceramus ex gr. galoi-haasti-subhaasti (Stevens, 1965a, p. 171).

The presence of elements of the $B$. uhligi complex in the Kimmeridgian-upper Tithonian rocks of the Argentinian Cordillera has already been pointed out by Stevens (1965a, p. 159, note; p. 137, note). However, all better preserved fragments of Belemnopsis spp. from the lower fauna of Hole 511 appear to be comparable with the New Zealand, Indonesian, and Himalayan representatives of the uhligi complex instead of being comparable with B. patagoniensis Favre, 1908 and allied 
forms (e.g., Feruglio, 1936, pl. X, figs. 1-4, 20) of the western Argentinian Cordillera. The Tithonian Belemnopsis faunas of the Antarctica recently described by Willey (1973) are also more closely allied to our fauna than are the Argentinian Belemnopsis faunas. Because of the invariably fragmental preservation of $B$. ex gr. uhligi and other belemnites of the lower fauna, only their tentative identifications with the previously described Indo-Pacific species will be attempted in this chapter.

One important element of the lower belemnite fauna is represented by stem fragments of what appear to be late juvenile representatives of $B$. moluccana (Boehm, 1907). These specimens were found in Samples 511-64-3, 147-148 cm (Pl. 2, Fig. 3), 511-67-1, 44-46 cm (Pl. 2, Fig. 7), and 511-67-3, 74-75 cm, and so range pretty well through the beds containing this fauna in the lower upper Tithonian to middle Kimmeridgian beds (Fig. 2). These $B$. cf. moluccana (compare the somewhat larger, half-grown specimens figured by Stolley, 1929, pl. 2, figs. 10-11) combine such characteristic features of the Indonesian species as a markedly depressed cross-section and a slightly fusiform shape of the guard with a round-bottomed medioventral canal that is extremely wide (up to two-fifths of the ventral face) and deep (almost one-half of dorso-ventral diameter). Furthermore, some of them (e.g., the specimen from Sample 511-64-3, $147-148 \mathrm{~cm}$ ) exhibit the strong decay and exfoliation of shell layers near the oral end that are characteristic of the alveolar part of the guard in B. moluccana where it also extends onto the adjacent part of the stem region.

Another Belemnopsis form comparable to our B. cf. moluccana is B. sp. A of Challinor (1979, p. 118, figs. 2, $66,67)$. However, it differs in the apparent absence of any decay and exfoliation of the layers of the guard at the oral end of its preserved stem region.

The second important element of the lower belemnite fauna is the three fragments of the stem region (in one case some of the apical region is included) of moderately sturdy Belemnopsis, distinctly to markedly and evenly adapically tapering (i.e., slightly to regularly conically shaped) that were found in the middle part of its range in the lower upper Tithonian to middle Kimmeridgian unit (Samples 511-66-1, 24-25 cm, 511-66-2, 91-92 cm [Pl. 2, Fig. 4], and 511-66-4, $46 \mathrm{~cm}$ [Pl. 2, Fig. 5; slightly conical]). These fragments are apparently comparable only with the distinctly conical to slightly conical representatives of B. stolleyi (Stevens, 1965b, pp. 622-626, pl. 95, figs. 1-3, 4-6, text-fig. 1b) because they have a similarly conical outline (they range from less conical to only slightly conical in dorso-ventral aspect) and moderately slender proportions, combined with an approximately equidimensional and rounded cross-section and a deeply incised medioventral canal that is relatively more narrow than in $B$. moluccana. However, these fragments are considerably smaller than the adult representatives of $\boldsymbol{B}$. stolleyi figured by Stevens and so are probably its half-grown to late juvenile representatives.

Two more specifically identifiable Belemnopsis specimens of the lower belemnite fauna occur in Sample 51166-3, 1-2 cm and near the base of the unit in Sample 511-67-2, 95-96 cm (Pl. 2, Fig. 15). These stem frag- ments are tentatively identified as half-grown representatives of $B$. keari s.l. (i.e., inclusive of $B$. alfuricus Stevens? non Boehm, B. maccrawi Challinor, and $B$. annae Challinor). In general shape and proportions these specimens resemble the evolutionarily more advanced, half-grown representatives of $B$. keari reproduced by Stevens (1965a, pl. 4, figs. 5-7; pl. 5, figs. 4-6) and Challinor (1979, figs. 43-50), which are, however, more nearly subcylindrically shaped. Like Stevens's and Challinor's specimens, these fragments have a deep and broad medioventral canal; the apical end shows a characteristic change from a distinctly depressed cross-section (Pl. 2, Fig. 15F) to a slightly compressed oral crosssection (Pl. 2, Figs. 2D, 15E). The apical fragment found in Sample 511-67-5, $91 \mathrm{~cm}$ (Pl. 2, Fig. 9) in the underlying lower Kimmeridgian and ?Oxfordian unit appears to represent the same growth stage of $B$. keari, which is even more typical of those representatives described as B. alfurica by Stevens (1965a). It complements the two stem fragments just described.

Apical fragments of juvenile Belemnopsis were found in Samples 511-67-1, 44-46 cm and 511-67-3, 74-75 cm. They are extremely attenuated and slowly and more or less evenly adapically tapering, acute-apicated, and small (up to $25 \mathrm{~mm}$ long and up to $4.5 \mathrm{~mm}$ in diameter) to tiny. These fragments cannot be compared with any previously described Belemnopsis species of which the corresponding growth stages have been described and figured, and they are tentatively designated Belemnopsis n.sp. indet. juv. in this chapter (Fig. 2). So far as I know, all comparably early juvenile stages of other $\mathrm{Bel}$ emnopsis tend to be more pronouncedly fusiform than the adult to half-grown forms, but retain a much more obtusely apicate and convexly shaped apical region (e.g., Stevens, 1965a, pl. 4, figs. 8-10; pl. 5, figs. 1-3, 7-9; pl. 7 , figs. $1-3$; pl. 9, figs. 7-9, 13-15; pl. 11, figs. 7-9). Neither of these apical fragments was figured; instead I have reproduced a considerably longer (about $36 \mathrm{~mm}$ ) but otherwise entirely similar fragment of the apical and lower stem regions found in Sample 511-67-5, 50-52 cm (Pl. 2, Fig. 8) in the underlying lower Kimmeridgian and ?Oxfordian unit, because it provides a far better idea of their morphology.

The shape and proportions of these apical fragments are similar to those of the much larger apical region of adult representatives of $B$. gerardi (Oppel, 1863) sensu Stevens (1963a, pl. 98, figs. 1-8). However, they cannot represent the still undescribed juvenile growth stages of this species because of the exceptional width and depth of their round-bottomed medioventral canal, which does not resemble that of $B$. gerardi (see Stevens, 1963a, pl. 98 , figs. 1-8) but instead closely resembles that of $B$. moluccana. The same appears true of $B$. cf. stolleyi, the juvenile fragment of which (i.e., that found in Sample 511-66-4, 46; Pl. 2, Fig. 5) resembles those juvenile fragments closely in the shape and proportions of its partly preserved apical region but differs in the considerably shallower and narrower appearance of its medioventral canal.

After the first appearance of $B$. cf. moluccana in Sample 511-64-3, 147-148 cm, the core interval from $511-64-4,88 \mathrm{~cm}$ through $511-64-5,87-88 \mathrm{~cm}$ to $511-64-$ 
$6,17-18 \mathrm{~cm}$ yielded no Belemnopsis. The three stem fragments found at those levels in this interval are closely similar to the Hastites-like stem fragments that form part of the upper fauna, from Samples 511-64-1, 36-37 $\mathrm{cm}$ and 511-64-2, 131-132 $\mathrm{cm}$. The best preserved small specimen found in Sample 511-64-6, 17-18 cm (Pl. 2, Fig. 1) lacks the apical region. It exhibits an Actinocamax-like alveolar end and appears to lack entirely either a medioventral canal or a medioventral furrow. This combination of features strongly suggests that it belongs to Hastites. The unfigured small specimen found in Sample 511-64-4, $88 \mathrm{~cm}$ exhibits exactly the same combination of features.

According to Stevens (1965a, p. 139, table 13) B. moluccana forms part of the lower phase of the uhligi complex proper and is of a later mid-Kimmeridgian age. It is younger than the Indonesian Demù Limestone containing $B$. cf. keari in association with $B$. alfurica (Boehm)? non Stevens 1965. The Demù Limestone, which was assigned to the middle to lower Kimmeridgian by Stevens, appears to be correlative with the $B$. keari Zone of New Zealand. Considering the presence of other Belemnopsis fragments comparable to B. moluccana in Samples 511-67-1, 44-46 cm and 511-67-3, $76-75 \mathrm{~cm}$ and the presence of evolutionarily advanced, presumably earliest mid-Kimmeridgian forms of $B$. cf. keari in Samples 511-66-3, 1-2 cm and 511-67-2, 95-96 cm (Fig. 2), most or all of the lower belemnite fauna of the lower lower Tithonian to middle Kimmeridgian beds of Hole 511 is of middle Kimmeridgian age. According to Sijvens (1965a, p. 628) B. moluccana was probably collected from "roughly the same bed as $B$. stolleyi as the writer found the two species intermingled in Weber's collections. Elsewhere in Indonesia (e.g., Misol) Buchia malayomaorica is associated with $B$. moluccana." Belemnopsis cf. stolleyi from Hole 511 indicates, therefore, the same age for the lower belemnite fauna as does $B$. cf. moluccana.

The presence of two specimens of $B$. cf. keari s.l. in Sample 511-66-3, 1-2 cm, and near the base of the lower upper Tithonian to middle Kimmeridgian unit (in Sample 511-67-2, 95-96 cm; Pl. 2, Fig. 15) provided a link to the belemnite fauna of the underlying lower Kimmeridgian and ?Oxfordian unit, where this species is the dominant determinable element. Therefore, all specifically determinable elements of the lower belemnite fauna of the lower upper Tithonian to lower Kimmeridgian unit indicate that the unit is middle Kimmeridgian in age and that it corresponds with part or all of the so-called "lower phase" of the uhligi complex. Below this unit, the lower Kimmeridgian and ?Oxfordian beds of Hole 511 correspond to the lower Kimmeridgian part of the Heterian Regional Stage of New Zealand (Stevens, 1978 , vol. 1 , pp. 224,225 , table 4.11 ) because $B$. cf. keari s.l. is prevalent in both faunas (see later for further details).

Summarizing, the specific composition of the lower belemnite fauna of the lower upper Tithonian to middle Kimmeridgian beds, its association with Malayomaorica occidentalis n.sp., and its occurrence stratigraphically below the lower upper Tithonian Virgatosphinctes ex gr. densistriatus-denseplicatus fauna indicate that this fauna corresponds with the early or mid-Kimmeridgian phase of the B. uhligi complex (Stevens, 1965a, p. 139, table 13).

\section{Inoceramus Fauna}

Numerous Inoceramus (s.l.) fragments encountered in the lower part of the lower upper Tithonian to middle Kimmeridgian beds (e.g., in Samples 511-64-3, $83 \mathrm{~cm}$, 511-64-4, 39-40 cm, 511-65-1, 70-80 cm, 511-65-2, 143$144 \mathrm{~cm}, 511-65-3,15-18 \mathrm{~cm}, 511-65-4,98-99 \mathrm{~cm}, 511-$ $65-4,150-151 \mathrm{~cm}, 511-65-5, \mathrm{CC}$; 511-66-2, 38-40 cm, $511-66-2,114-116 \mathrm{~cm}$, and 511-67-2, 95-96 cm) are all fairly large forms considerably exceeding the diameter of the core. They are invariably characterized by a prominent, sharp-topped, widely spaced, concentric ornament consisting of subequally wide and prominent ribs and intercostal spaces. These specimens may well belong to the I. haasti-subhaasti species group (Fig. 2). However, all specimens seen were too fragmentary to be assigned definitively to any of the Late Jurassic species groups of Indo-Pacific Inoceramus s.1. Furthermore, all of them deteriorated so as the sediment dried following the first investigation of the core that it was impossible either to study them further or to photograph any of them.

\section{Lower Kimmeridgian and ?Oxfordian Beds: Belemnopsis cf. keari Beds}

Sections 511-67-4 to 70-5 inclusive (i.e., to the bottom of Hole 511) yielded a fauna of buchiid pelecypods and belemnites that differs from that of the overlying lower upper Tithonian to middle Kimmeridgian unit. It is designated herewith the lower Kimmeridgian and ?Oxfordian beds, for reasons to which I now turn.

A considerable number of readily identifiable right and left valves of Jeletzkiella falklandensis Jones and Plafker, 1977 were recovered from Samples 511-68-1, 26 $\mathrm{cm}, 511-68-1,101-103 \mathrm{~cm}$ (Pl. 1, Fig. 10), 511-68-1, $127-128 \mathrm{~cm}$ (Pl. 1, Fig. 12), and 511-68-2, 4-6 cm. These specimens of $J$. falklandensis are the only pteriid pelecypods encountered in the basal unit of Hole 511, except for a doubtful fragment of Malayomaorica sp. in Sample 511-68-2, 4-6 cm. The characteristic bladelike anterior ear of the right valve (Jones and Plafker, 1977, p. 347 , pl. 2, fig. 9) is broken off in all of the right valves of $J$. falklandensis studied (e.g., Pl. 1, Fig. 10D). This mutilated anterior ear (see also Jones and Plafker, 1977, pl. 2, figs. 3,12 ) resembles superficially that of the basal Cretaceous Arctotis ex gr. intermedia-anabarensis (see Zakharov, 1966, pl. III, figs. 11, 12a, 12b; pl. IV, figs. 3b, 4b) and ?Arctotis n.sp.A (Pl. 1, Figs. 11B, D) of Hole 511. However, the characteristic Buchia-like shape of these right valves combined with a total absence of radial ornament (Pl. 1, Figs. 10C, 12A) permit safe differentiation of the two. The orientation of the right anterior ear in the plane of symmetry of the valves distinguishes $J$. falklandensis from Malayomaorica. The left valves of $J$. falklandensis (Pl. 1, Fig. 12F) differ sharply from those of Arctotis in the presence of a transversal furrow, obliquely directed and shallow but otherwise 
like Malayomaorica (this is the sulcus of Jones and Plafker, 1977, p. 347) that crosses the ligamental plate beneath the small beak. Another feature distinguishing the left valve of $J$. falklandensis from Arctotis and Malayomaorica is the position of the prominent anterior bulge of the ligamental plate, either directly or almost directly beneath the beak and next to the transversal furrow (Pl. 1, Fig. 12F). In the studied material of J. falklandensis, however, the degree of inclination and the depth of the transversal furrow of the left ligamental plate vary considerably. The furrow may resemble that of some representatives of $M$. occidentalis $\mathrm{n}$. sp. from the higher levels of Hole 511 (e.g., Pl. 1, Fig. 8E). This feature, taken in combination with the similar sculpture of these two forms, where concentric layers overlap like shingles and radial ornament is absent, suggests that $M$. occidentalis $\mathrm{n} . \mathrm{sp}$. is a descendant of Jeletzkiella. Their stratigraphic relationships agree well with this hypothesis.

Like the lower belemnite fauna of the preceding lower upper Tithonian to middle Kimmeridgian beds, the belemnite fauna of the lower Kimmeridgian and ?Oxfordian beds is dominated by representatives of the genus Belemnopsis. However, in most instances its Belemnopsis forms appear to be specifically different.

The fragments of the stem, apical, and alveolar regions (Pl. 2, Fig. 15, Pl. 2, Figs. 9, 13, and Pl. 2, Fig. 2, respectively) of fairly small to moderately large, slender belemnites, which are apparently referable to halfgrown to adult representatives of Belemnopsis cf. keari s.l., represent the most numerous and biochronologically most important element of this belemnite fauna. No fewer than eight of these fragments were found. The adult specimens were in Samples 511-67-4, 9-10 cm (Pl. 2, Fig. 13) and 511-70-3, 84-85 cm (Plate 2, Fig. 2A2D); the half-grown specimens were in Samples 511$67-4,15-16 \mathrm{~cm}, 511-67-4,89 \mathrm{~cm}, 511-67-5,19 \mathrm{~cm}, 511-$ 67-5, $91 \mathrm{~cm}$ (Pl. 2, Fig. 9), 511-?68-1, 138-139 cm, and 511-69-2, 121-122 cm. They represent the largest component of the fauna and range almost throughout the whole thickness of the lower Kimmeridgian and ?Oxfordian beds.

In the last section I explained why the six half-grown fragments should be compared with $B$. keari s.l. The fragment of the lower alveolar and adjacent postalveolar segment of a large, presumably adult belemnite (P1. 2, Fig. 2) found in Sample 511-70-3, 84-85 cm also exhibits the characteristic features of $B$. keari s.l. It matches almost exactly the corresponding segments of the adult specimen CE415 figured by Stevens (1965a, pl. 3 , figs. 1-3), in its degree of adoral tapering, the width, depth, and shape of the medioventral canal, and the almost equidimensional (slightly compressed), approximately rounded alveolar cross-section. The apical fragment of another large, presumably adult specimen, from Sample 511-67-4, 9-10 (P1. 2, Fig. 13) resembles particularly closely the apical end of the specimen CE930 (Stevens, 1965a, pl. 5, figs. 10-12) in the prominence and width of its medioventral canal.

The second important element of this belemnite fauna is represented by four apical and stem fragments of a juvenile Belemnopsis form that is extremely slender, slowly and more or less evenly adapically tapering, and acute-pointed. It is designated as B.n.sp. indet. juven. earlier (Samples 511-67-1, 44-46 and 511-67-3, 74-75). The peculiar, presumably new Belemnopsis form was found in Sample 511-?67-4, 109-113 cm, in which there were specimens with shorter and less acute apical region and a more narrow and shallow medioventral canal that could also belong to the juvenile representatives of $B$. keari, and Samples 511-67-5, 50-52 cm (Pl. 2, Fig. 8), $511-67-5,69 \mathrm{~cm}, 511-68-2,68-69 \mathrm{~cm}$, and 511-68-2, $83-86 \mathrm{~cm}$. This Belemnopsis n.sp. indet. juven. is not known outside Hole 511 and so does not help in dating its lower Kimmeridgian and ?Oxfordian beds. However, it does attest to the close affinity of that belemnite fauna with the lower belemnite fauna of the lower upper Tithonian to middle Kimmeridgian beds immediately above.

The third, rather intriguing element of the belemnite fauna of the lower Kimmeridgian and ?Oxfordian beds is a Belemnopsis form that is rather sturdy (its estimated coefficient of elongation is 5 to 7 ) and short but distinctly fusiform. This was found in Samples 511-68-2, 55-56 $\mathrm{cm}$ (Pl. 2, Fig. 10), 511-69-1, 106-108 cm (Pl. 1, Fig. 6), and $511-69-4,53-54 \mathrm{~cm}$. This form, which is represented by an almost complete juvenile guard (Pl. 2, Fig. 10) and two fairly complete, apparently adult guards (e.g., Pl. 1, Fig. 6) is similar only to the more slender representatives of B. spathi Stevens (1965a, pp. 92-94, pl. 13) in the shape and proportions of the guard. However, the Hole 511 form differs from $B$. spathi in its considerably deeper, incised, medioventral canal, which is appreciably widened in the lower stem region and reaches almost to the apex. Furthermore, its cross-section appears to be distinctly compressed throughout (all three specimens are somewhat distorted), with somewhat flattened flanks (Pl. 2, Fig. 10D). The Hole 511 form is therefore interpreted as a new species allied to $B$. spathi Stevens. This species, which will be formally named later, is here designated provisionally as Belemnopsis $\mathrm{n}$. sp. aff. $B$. spathi Stevens. The New Zealand species is restricted (Stevens, 1965a, p. 92) to the upper Ohauan and lower Puaroan (late middle Kimmeridgian and lower upper Tithonian) beds of New Zealand, which are considerably younger than the lower Kimmeridgian and ?Oxfordian beds of Hole 511. The B. n.sp.aff. spathi of this hole could therefore belong to its ancestral stock.

The last specifically determinable element of the belemnite fauna here discussed is a sturdy and short medium-sized guard, regularly and pronouncedly conical, found in Sample 511-68-1, 11-12 cm (Pl. 2, Fig. 14). This fragmentary guard, which lacks the oral threefifths or so of the alveolar region and a considerable part of the apical region, is estimated graphically to be about $60 \mathrm{~mm}$ long and to have a maximum dorso-ventral diameter of $12-13 \mathrm{~mm}$. This should result in a coefficient of elongation ranging between 4.5 and 5. The alveolus is estimated to comprise between two-fiths and one-half of its restored length. The guard contracts evenly at about $15^{\circ}$ in the lateral aspect and at $8-9^{\circ}$ in 
the dorso-ventral aspect. The apical line is markedly adventrally depressed at the apical break and the fragment is distinctly compressed throughout.

The only Belemnopsis species known to exhibit most of these morphological features is $B$. orientalis (Waagen, 1873) (compared Spath, 1927, pp. 10, 11; pl. I, fig. 8 for the most up-to-date description and figures of this Himalayan species). So far as it is possible to see, our fragmentary guard differs from the figured specimen of $B$. orientalis only in its oval, markedly compressed crosssection (dorso-ventral diameter at oral end is about 11.4 $\mathrm{mm}$, whereas the lateral diameter is only $10.4 \mathrm{~mm}$ ). This cross-section contrasts with the slightly depressed, almost regularly circular oral cross-section of the figured representative of $B$. orientalis (Spath, 1927, pl. I, fig. 8). The specimen in Sample 511-68-1, 11-12 cm is therefore believed to be a specifically distinct ally of $B$. orientalis and is designated herein as $B$. aff. orientalis (Waagen) (Fig. 2).

The specimen in Sample 511-68-1,11-12 cm is somewhat similar to $B$. cf. stolleyi from the lower belemnite fauna of the overlying lower upper Tithonian to middle Kimmeridgian beds (compare Pl. 2, Figs. 4-5). However, this $B$. cf. stolleyi contracts adapically at a considerably smaller angle (about $5^{\circ}$ in the lateral aspect and $4.5^{\circ}$ in dorso-ventral aspect in the specimen from Sample 511-66-2, 91-92 cm; Pl. 2, Figs. 4A, B) and is estimated to be considerably more slender than either $B$. stolleyi or $B$. aff. orientalis of Hole 511. Furthermore, B. cf. stolleyi has a equidimensional to slightly depressed oral cross-section resembling that of the $B$. orientalis from the Kachh Beds of India. The original B. stolleyi differs even more strongly from the $B$. aff. orientalis from Hole 511 and the two forms are obviously less closely related to $B$. aff. orientalis than is $B$. orientalis from the Kachh Beds.

The Belemnopsis fragments found in Samples 51167-4, 83-84 cm, 511-67-5, 33-34 cm, 511-67-5, 74-77 $\mathrm{cm}, 511-68-2,118-119 \mathrm{~cm}$, and $511-69-3,21 \mathrm{~cm}$ are specifically indeterminate.

The only larger fragment of Inoceramus extracted from the lower Kimmeridgian and ?Oxfordian beds (i.e., from Sample 511-70-4, 136-137 cm; Pl. 1, Fig. 16) occurs near the bottom of Hole 511, stratigraphically below the lowest specimen of Belemnopsis $\mathrm{cf}$. keari s.l. (Sample 511-70-3, 84-85; Pl. 2, Fig. 2) and a fragment of a peculiar but generically indeterminate ammonite (Sample 511-70-3, 22-23 cm; Pl. 1, Fig. 4). This Inoceramus fragment is ornamented by simple and prominent ribs separated by shallow interspaces which are two to three times wider than the ribs proper. The ribs are sharptopped and form regular arches. This ribbing habit matches closely that of $I$. galoi (Boehm) as exemplified by the specimen figured by Speden and Keyes (1981, pl. 17, fig. 17). However, the species and species group of the fragment cannot be determined definitely.

The apparent restriction of Malayomaorica occidentalis n.sp. to the overlying lower upper Tithonian to middle Kimmeridgian beds (except possibly for one fragment of the right valve in Sample 511-68-2, 4-2 cm) is the best indication of the pre-middle Kimmeridgian age of the lower Kimmeridgian and ?Oxfordian beds of Hole 511. In New Zealand, where the time range of Malayomaorica is best known, it does not seem to range appreciably (if at all?) below the middle/lower Kimmeridgian boundary, which is placed between the Idoceras and Kossmatia zones within the Heterian Regional Stage (Stevens, 1978, vol. 1, p. 226, table 4.11). Therefore, I have placed the middle/lower Kimmeridgian boundary in Hole 511 at the bottom of Section 511-673 , slightly below the lowest known occurrence of $M$. occidentalis $\mathrm{n}$. $\mathrm{sp}$. in Sample 511-67-2, 65-67 cm. The first appearance of $B$. cf. keari s.1. in Sample 511-67-2, 95-96 $\mathrm{cm}$ is also suggestive of the early mid-Kimmeridgian age of these beds, because B. keari s.l., as I interpret it later in this chapter, appears to cross the middle/lower Kimmeridgian boundary in New Zealand.

The concept of $B$. keari that I am using must be explained before I attempt to date the $B$. cf. keari fauna of the lower Kimmeridgian and ?Oxfordian beds of Hole 511. I accept Challinor's (1979, p. 115) proposal to synonymize the New Zealand examples of $B$. alfurica Stevens, 1965 with $B$. keari Stevens, 1965 on the specific and subspecific levels. In New Zealand these two forms are associated in the upper part of the B. keari Zone (Stevens, 1965a, p. 132) and are barely distinguishable in typical examples, let alone transitional forms, throughout the range of $B$. alfurica. Therefore, the two "species" are no more than morphological variants of the same polytypic species. It may well be that the type material of B. alfurica Boehm, 1907 (Stevens, 1963b, pp. 101-103, pl. 1, figs. 1-7) and its other Indonesian material (e.g., Stevens, 1963b, pl. 1, figs. 8-13; Stevens, 1965 a, pp. 137-145, table 13) are also mere morphological variants of $B$. keari. If so, $B$. alfurica Boehm, 1907 would become a senior synonym of $B$. keari Stevens, 1965. However, this problem is beyond the scope of this chapter.

Although I accept the synonymy of the New Zealand examples of $B$. keari and B. alfurica, I believe that Challinor's $(1979$, pp. 197, 111) proposal to exclude the early forms of $B$. keari from that species and to erect two new species, B. annae Challinor, 1979 and B. maccrawi Challinor, 1979, for these and other forms from the upper Oraka Sandstone and Ohineruru Formation is impractical, even on a regional scale within New Zealand. Challinor's new species are probably either morphologically extreme representatives of the early populations of $B$. keari s.l. or, at the very most, its chronological subspecies. Whatever their true nature, $B$. annae and $B$. maccrawi cannot be recognized by a foreign worker who deals with geographically remote, scarce, and fragmentary material that is comparable only with $B$. keari in the broad sense as just outlined. This $B$. keari s.l. is a long-ranging species, which makes its first appearance in the lower Heterian (i.e., upper Oraka Sandstone) and disappears in the upper Heterian (i.e., somewhere in the lower Kowhai Point Siltstone). This time range (the combined time ranges of $B$. keari and $B$. alfurica provided by Stevens, 1978 , vol. I, p. 224 , table 4.11 ) corresponds to most of the lower Kimmeridgian and lower part of the middle Kimmeridgian Stage as interpreted by 
the New Zealand geologists. The uppermost occurrences of $B$. cf. keari s.l. low in and near the base of the upper lower Tithonian to middle Kimmeridgian beds (i.e., in Samples 511-66-3, 1-2 and 511-67-2, 95-96 cm) appear to represent the upper, early mid-Kimmeridgian part of its time range because of the previously mentioned association with $M$. occidentalis n.sp. All other occurrences of $B$. cf. keari s.l. in the lower Kimmeridgian and ?Oxfordian beds appear to represent the early Kimmeridgian part of the range because they are stratigraphically below the range of $M$. occidentalis n.sp.

The Jeletzkiella falklandensis fauna commonly present in Sample 511-68-1, $26 \mathrm{~cm}$ and in the interval from $511-68-1,101-103 \mathrm{~cm}$ to $511-68-2,4-6 \mathrm{~cm}$ of the lower Kimmeridgian and ?Oxfordian beds is evidently correlative with its counterpart in the adjacent DSDP Site 330, where Jones and Plafker (1977, p. 848) encountered $J$. falklandensis fauna stratigraphically below the $M$. cf. $M$. malayomaorica, which appears to be conspecific with $M$. occidentalis $\mathrm{n}$. sp. of Site 511 .

According to Jones and Plafker (1977, p. 848), " Jeletzkiella falklandensis occurs in Sample 330-8,CC and in Section 1 of Core 9 (Table 1), which is stratigraphically below the interval characterized by $M$. cf. M. malayomaorica of probable early to middle Kimmeridgian age. An early Kimmeridgian age also seems appropriate for the upper range of Jeletzkiella, but the age of the underlying specimens from Core 9 might be as old as late Oxfordian."

The diagnostic macrofossils of the lower Kimmeridgian and ?Oxfordian beds of Hole 511 that have just been discussed do not provide a definitive answer as to whether this unit includes any Oxfordian beds in addition to the lower Kimmeridgian beds.

Unlike Jones and Plafker (1977, p. 848), I do not think that the $J$. falklandensis fauna as such necessarily ranges down into the late Oxfordian. First, the most recent recognition of the apparently exclusively middle Kimmeridgian to early late Tithonian age of Malayomaorica fauna in New Zealand leaves the whole of the early Kimmeridgian as a possible time range for the $J$. falklandensis fauna. Second, the J. falklandensis fauna is associated with the apparently mid- to early Kimmeridgian B. cf. keari s.l. fauna in Hole 511 (see earlier, and Fig. 2). Third, B. cf. keari s.l. ranges well below $J$. falklandensis in the lower Kimmeridgian and ?Oxfordian beds (e.g., the specimen in Sample 511-70-3, 8485 ). Fourth, and last, the presumably early Kimmeridgian Inoceramus sp. ex gr. I. galoi (e.g., Stevens, 1978 , vol. 1, pp. 224, 225, table 4.11; Stevens and Speden, 1978, pp. 264, 266, table II) was found in the lowest beds of Hole 511 (i.e., in Sample 511-70-4, 136-137 $\mathrm{cm}$; Pl. 1, Fig. 16) well below the lowest bed carrying $J$. falklandensis. For these reasons, all beds containing this species in Hole 511 are placed tentatively in the lower Kimmeridgian.

The age of Cores 69 and 70, underlying the core that carries the $J$. falklandensis fauna, is another matter because the evidence of macro- and microfossils is apparrently contradictory. Both coccoliths and dinoflagellates suggest the possibility of an early Oxfordian age for
Core 70 (Wise, this volume). At first sight, this conclusion appears incompatible with the evidence of belemnites and $I$. sp. ex gr. galoi found in Core 70. As already explained, it is accepted in the most recent Indo-Pacific literature that neither $B$. keari s.l. nor $I$. ex gr. galo $i$ range down into Oxfordian rocks. Furthermore, there is no evidence that the lowest beds (i.e., Core 70 ) reached in Hole 511 represent the lowest part of the B. keari s.l. Zone. As Stevens pointed out (1965a, p. 132) and subsequent research into the New Zealand material confirmed (e.g., Stevens, 1978, vol. 1, pp. 224, 225, table 4.11), these basal beds of the Heterian stage are characterized by an association of early forms of B. keari and Conodicoelites spp. However, no representatives of Conodicoelites were encountered in the basal cores of Hole 511. The presence of $I$. sp. ex gr. galoi in the lowest beds (e.g., in Sample 511-70-4, 136-137; Pl. 1, Fig. 16) also seems to argue against an age earlier than early Kimmeridgian, as these Inoceramus forms are not known to range down into the late Oxfordian either (Stevens, 1965a, pp. 138, 139, table 13).

The presence of such forms as $B$. aff. orientalis in the middle part (i.e., in Sample 511-68-1, 11-12 cm; Pl. 2, Fig. 14) of the lower Kimmeridgian and ?Oxfordian beds does not necessarily suggest an age earlier than the early Kimmeridgian. The Himalayan representatives of $B$. orientalis are derived from the Dhosa Oolite of the Kachh region, which is early Oxfordian (i.e., Argovian, Aspidoceras perarmatus Zone) in age (Spath, 1927, pp. 10, 11; Stevens, 1965a, p. 148, table 14). However, $B$. aff. orientalis of Hole 511 is not conspecific with this Kachh form and so could be its early Kimmeridgian descendant.

It must be pointed out, however, that the bulk of this evidence is only suggestive. For example, only partial zones (= Teilzones) of $B$. keari s. lato, Conodicoelites spp., and $I$. ex gr. galoi appear to be known in New Zealand, where these fossils have been studied in the greatest detail. As Stevens pointed out (1978, vol. 1, p. 227):

\footnotetext{
No definite Upper Callovian or Oxfordian fossils are known from New Zealand and this gap falls between the Temaikan (Bajocian-middle Callovian) and the Heterian (lower and middle Kimmeridgian; Table 4.11). At Kawhia the Temaikan assemblage in the Opapaka Sandstone is separated from the lowest Heterian assemblage in the Oraka Sandstone by the non-marine Wharetanu Measures. This formation, together with a possible unrecognized disconformity, may represent the missing upper Callovian and Oxfordian, as well as the lower and middle Callovian (upper Temaikan) that Speden (1970) has shown to be missing in the Kawhia section.

In the Southland where the Upper Temaikan is present, it is succeeded by non-marine beds (Speden, 1961b) that may represent the Upper Callovian and Oxfordian. In the Awakino region (Grant-Mackie, 1959), Upper Temaikan beds pass without apparent break into Heterian beds.
}

Under such circumstances the lowest known occurrences of B. keari s.l., Conodicoelites spp., and $I$. ex gr. galoi-haasti-subhaasti in association with the basal Kimmeridgian Epicephalites in the Oraka Sandstone do not need to represent the basal parts of their total time ranges (i.e., biozones). Those lowest time ranges could well be in the still unknown marine equivalents of either the Wharetanu Measures or the inferred hiatus separat- 
ing lower Kimmeridgian and middle Callovian marine rocks throughout New Zealand.

The Upper Jurassic rocks of Indonesia contain most or possibly all of the New Zealand species of belemnites, buchiid pelecypods, and Inoceramus and appear to include at least some marine Oxfordian beds missing in New Zealand. Unfortunately the stratigraphic sequence of these faunas is too poorly known to answer the question about the total time ranges (biozones) of $B$. keari s.I. and $I$. ex gr. galoi. The apparent absence of Conodicoelites spp. in the lowest beds (Core 70 ) reached by Hole 511 may well be an accident of the coring process, in view of the relative scarcity of the belemnites found.

Under such circumstances and considering the tentative character of identifications of all presumably early Kimmeridgian Belemnopsis and Inoceramus species found in the lowest beds of Hole 511, stratigraphically below the lowermost occurrence of J. falklandensis, one cannot say that these macrofossils definitely conflict with the tentative identification of the lower Oxfordian coccolith and dinoflagellate assemblages in Core 70 . I have decided to leave the age of these beds open for the time being, and have accordingly designated the basal biochronological unit of Hole 511 as lower Kimmeridgian and ?Oxfordian beds.

\section{REMARKS ON PALEOENVIRONMENTS OF MACROINVERTEBRATE FAUNAS}

\section{Albian Paleoenvironments}

The Albian Sections 511-50-1 to 511-57-1 consist of orange to greenish grey or beige clays and marls, which contain numerous interbeds and pods of pelecypod coquina and other interbeds and pods where the clay or marl is enriched in scattered pelecypods. The pelecypod fauna of these interbeds and pods consists exclusively or almost exclusively of Aucellina radiatostriata. This species is always represented by accumulations of variously oriented, single valves which are for the most part either flattened or strongly deformed and cracked by the sediment pressure during their lithification. However, no traces of abrasion or chipping of shells, such as would indicate the action of stronger currents or waves, were observed. Other pelecypods with shallow-water affinities and solitary corals (e.g., in Samples 511-50-1, 23$103 \mathrm{~cm}$ or $511-50-1,103-108 \mathrm{~cm}$ ) are occasionally present as fragmentary specimens or fragments. Neither belemnites nor ammonites were observed in these coquinoid interbeds, which are separated by many thin to thick intervals of clay and marl that are unfossiliferous, except for occasional fragmentary solitary corals and pelecypods of shallow-water affinities. Generally speaking, these fossils are present in beds which exhibit signs of soft sediment deformation and/or slumping.

According to Krasheninnikov and Basov (this volume), these cores contain an outer neritic to uppermost bathyal foraminiferal fauna; they state that the Albian sediments (Cores 49-57) contain a moderately well preserved and diverse benthic foraminiferal fauna consisting mostly of shallow-water species (100 to $400 \mathrm{~m}$ shelf-break fauna): Dorothia trochoides, Glomospira corona, G. gordialis, Clavulina gabonica, Lenticulina sp., Uvigerinammina jankoi, Osangularia utaturiensis, Patellinella australis, Spirillina elongata, Gyroidinoides primitiva, Anomalinoides indica, Gavellinella intermedia, and Pleurostomella obtusa.

The presence of this shelf-break foraminiferal fauna seems to conflict with that of numerous interbeds and pods of pelecypod coquina consisting of disjointed single valves. Such interbeds and pods are normally confined to relatively high energy, inner neritic or littoral environments and were presumably deposited in depths less than 50 meters. However, these particular interbeds and pods are either dominated by $A$. radiatostriata or consist exclusively of that species. All Aucellina species I am familiar with are peculiar in being just as depth-tolerant as are the inoceramids and other buchiids. They are commonly associated with ammonites in known bathyal deposits, including deep-water flysch facies (e.g., in eugeosynclinal troughs of western British Columbia; Jeletzky and Tipper, 1968). The Aucellina coquinas and coquinoid interbeds of Sections 511-50-1 to 511-57-1 are, therefore, believed to reflect the influence of bottom currents that intermittently swept the bottom of the outer neritic to upper bathyal parts of the Albian basin where Hole 511 was drilled. According to this interpretation, these sediments were deposited in a well-aerated but normally muddy, low-energy environment. The mass occurrence of Aucellina on such a soft substratum devoid of any appropriate attachment surfaces for their byssus threads was made possible by the bottom currents, which must have been removing enough mud to permit successive generations of Aucellina to settle on the shells of their dead predecessors. Flourishing Aucellina colonies were maintained in this fashion as long as the current persisted. Thereafter, they must have been smothered by the accumulation of mud and were able to reappear only during the next current pulse. Judging by their effects, these bottom currents must have been strong enough to disjoint the valves of all Aucellina after death and to pile them up in a disordered fashion but not strong enough to significantly abrade or fragment them.

The occasional presence of fragmentary solitary corals or other pelecypods of shallow-water affinities in these coquinoid interbeds and pods and in the numerous, partly thick intervals of clays and marls between them appears to result from redeposition by sediment slumping from adjacent shallow-water areas. This hypothesis also adequately explains the presence of these unfossiliferous intervals and the total absence of belemnites.

The common presence of apparently inner-shelfbound pelecypods other than Aucellina in a few of the coquinoid Aucellina interbeds still presents a problem. Additional work on the ecology of these pelecypods is needed to explain their presence in this presumably shelfbreak environment.

\section{Late Aptian Paleoenvironments}

Sections 511-57-2 to 511-58-3 were apparently deposited in a bathyal (?upper) to perhaps outermost neritic, 
presumably anoxic environment (Ludwig et al., 1980, p. 659). This is indicated by an almost total absence of any pelecypods and a total absence of belemnites. Such very rare pelecypods as were observed (e.g., in Sample 511$58-3,53-54 \mathrm{~cm}$ ) were probably redeposited from the inner shelf of the Aptian basin by slumping and/or turbidity currents. The total absence of belemnites is particularly diagnostic of a deeper water paleoenvironment as these animals are known to be restricted to the shelf depths (Stevens, 1965a, pp. 168, 170,181). So far as is known, they did not commonly inhabit even the outermost parts of the shelf, below 100 to 150 meters.

The rare ammonites (Fig. 2) found in this core inter$\mathrm{val}$ are all depth-tolerant or nectoplanktonic types (e.g., the Australiceras? sp. found in Sample 511-58-1, 137$138 \mathrm{~cm}$ ). The rare Cerithium-like gastropods ( $\mathrm{Pl}$. 1, Fig. 1) also appear to be depth-tolerant types. Unlike the presumably current-swept Albian paleoenvironment, the Aptian paleoenvironment of Hole 511 was generally speaking a low-energy one. The only exceptions were the apparently fairly common episodes of soft-sediment slumping and turbidity currents.

\section{Early Aptian and ?Latest Barremian Paleoenvironments}

The sediments of Sections 511-58-4 to 511-60-4 inclusive and the upper $80 \mathrm{~cm}$ of Section 511-60-5 were definitely deposited in an inner neritic to littoral environment, presumably in a restricted marine environment in close proximity to either an outer bar or the shoreline of the basin. This depositional environment is indicated by the abundance of various thick-shelled, shallow-water pelecypods, including numerous oysters evidently not redeposited. These pelecypods commonly to prevailingly form coquinas. The common presence of belemnites, which are all but confined to the inner- to median-shelf environment (less than $150 \mathrm{~m}$ ), confirms the shallowwater environment of the sediments, but seems to clash with the presence of numerous oysters in the same beds. It is well established that belemnites require a normal to near-normal salinity regime whereas oysters thrive only in distinctly to markedly freshened waters, where they are protected from their stenohalinous enemies, such as octopi or starfish. Perhaps dead belemnite animals were carried into a restricted marine environment with a lowered salinity and their wear-resistant guards were deposited and buried on the beaches of this lagoon or estuary.

The inference of a fairly protected, moderate- to perhaps low-energy marine depositional environment for these sections permits an alternative interpretation of the sediments that are alternatively oyster- and belemnite-bearing. This fairly protected embayment, which could have been either an estuary or a large lagoon, may have experienced frequent alternation of an environment that was about normally saline with one that was distinctly brackish (presumably delta-influenced). The major shallowing episode discussed above began and ended abruptly, geologically speaking.

Unlike the late Aptian outermost neritic or upper bathyal argillaceous sediments of Sections 511-57-2 to 511-58-3, the early Aptian and ?latest Barremian sedi- ments were not deposited in an euxinic bottom environment. Their rich, bottom-dwelling, partly sediment-burrowing pelecypod fauna indicates a normally aerated condition at the sea bottom and at least in the upper sediment layers. The suggestion by Ludwig et al. (1980) of continuously anoxic deposition for the Barremian-Aptian and Upper Jurassic beds of Unit 6 of Hole 511 is therefore an oversimplification, as I also note later in this chapter.

\section{Barremian Environment}

The lower $70 \mathrm{~cm}$ of Section 511-60-5 to the bottom of Core 62 , inclusive, were apparently deposited almost exclusively, possibly except for Sections 511-62-3 to 511$62-5$ in the same bathyal to outermost neritic, presumably anoxic environment as the upper Aptian rocks represented by Sections 511-57-2 to 511-58-3, inclusive. This is indicated by their exclusively organic-carbonenriched, argillaceous lithology and the almost complete absence of invertebrate macrofossils. The pelecypods are almost totally absent, except for a couple of fragmentary, presumably depth-tolerant aviculopectinid shells that could also have been redeposited from adjacent shelf areas. Only a couple of poorly preserved belemnite fragments, which could have been either redeposited by slumping or turbidity currents from the adjacent shelf or transported in the stomachs of carnivorous animals, were observed.

Scales and other skeletal remnants of fishes are commonly present in these cores. This feature, like the rare presence of indeterminate ammonites, is commonly encountered in, although by no means restricted to, deepwater deposits.

The depositional environment of the core interval discussed here must have been, generally speaking, one of very low energy (an euxinic environment for the most part) with episodes of soft-sediment slumping and turbidity currents that were less common than in Sections 511-57-2 to 511-58-3.

The lowest part of this interval, from 511-62-3, 129 $\mathrm{cm}$ to the base of Section 511-62-5, differs in that invertebrate fossils are more frequently present. These include several well-preserved, presumably not redeposited belemnites (e.g., Hibolithes sp. indet. B; Pl. 2, Figs. 11-12), some Inoceramus sp., and a Dentalium (s.1.) sp. The appearance of shallow-water invertebrate types indicates that the Barremian interval of deep-water deposition began with a shallower phase, then experienced a pronounced deepening trend and finally ended in another shallowing phase. Considering the presence of a prolonged hiatus (Hauterivian to late or ?mid-late Tithonian; see Fig. 3) at the base of these deep-water cores, the initial shallower water phase of this transgression cycle registers the onset of the Barremian transgression upon the bevelled Hauterivian (or perhaps early Barremian) landmass that had apparently occupied the area since the late or ?mid-late Tithonian regression.

This initial report is not an appropriate place to argue at length whether or not the rapid Aptian to Barremian fluctuations of the sea depth from a bathyal and/or outermost neritic depth (Sections 511-57-2 to 511-58-3) 


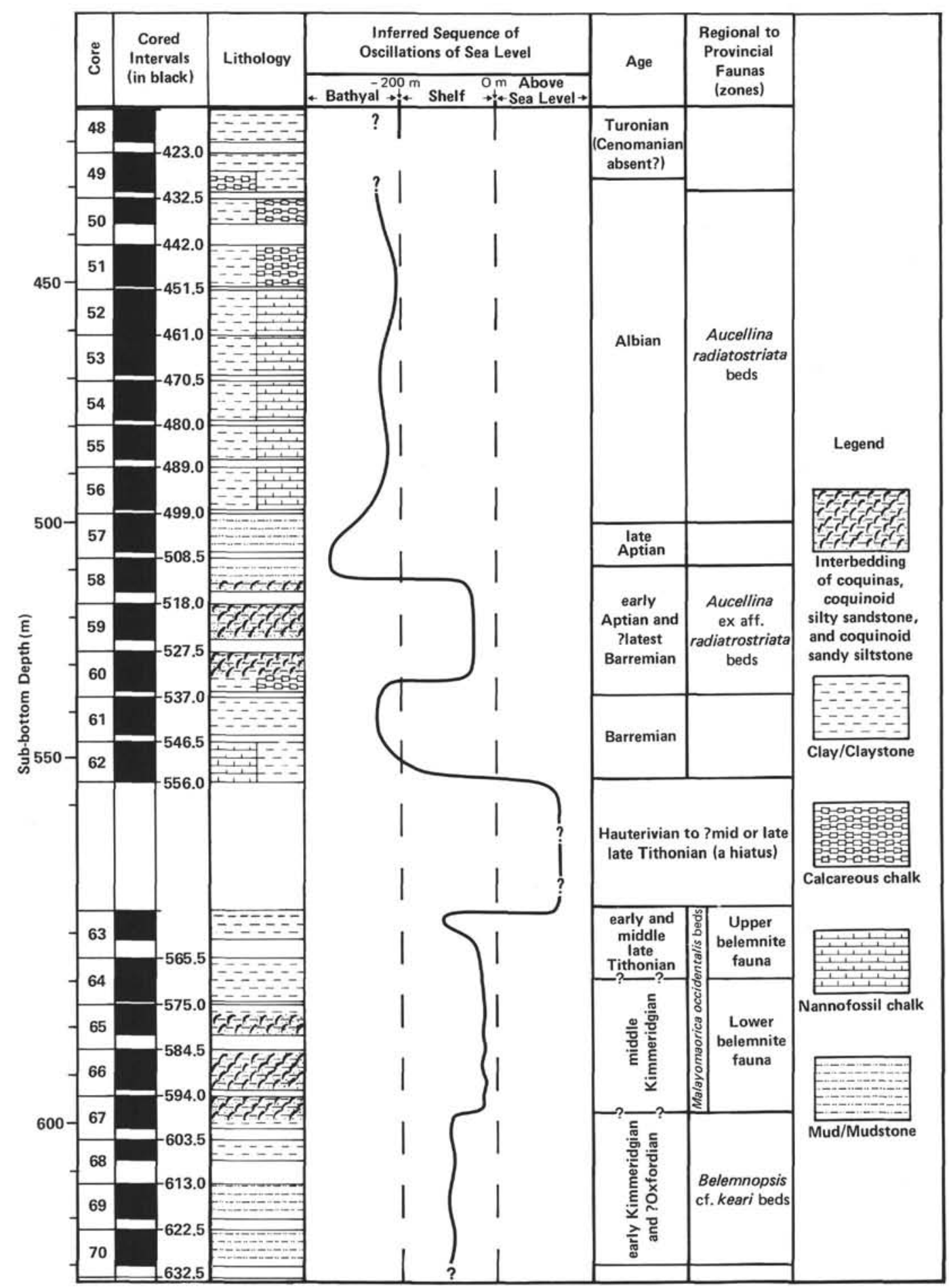

Figure 3. Late Jurassic and Early Cretaceous environmental and bathymetric history of DSDP Hole 511.

to innermost neritic or littoral depth (Sections 511-58-4 to 511-60-4 and the upper $80 \mathrm{~cm}$ of Section 511-60-5) and then back again (i.e., lower $70 \mathrm{~cm}$ of Section 51160-5 to the bottom of Section 511-62-5) were caused eustatically or epeirogenically. However, the early Aptian to ?latest Barremian time represented by the very shallow water interval from Section 511-58-4 to 511-60-4 inclusive (Fig. 3) was characterized by widespread regres- sion of the sea. According to Kauffman (1973, p. 364, fig. 7) this regression (he called it Regression 3) was a global, eustatically caused epeiric sea event. However, this conclusion was disputed by Jeletzky (1978, pp. 1617 , fig. 10), who was able to register this regressive phase in only some Canadian depositional basins. The contemporary regimes of other Canadian basins were found to be pronouncedly transgressive instead. Fur- 
thermore, Jeletzky (1978, pp. 22-23, fig. 1) found similar discrepancies in the oscillatory regime in a number of other Cretaceous depositional basins around the globe.

It is interesting to note also that this early Aptian to ?latest Barremian shallowing phase must have been very brief, geologically speaking. It could only have lasted through the early half of the Aptian at the very most (possibly exclusive of the Tropaeum gigas beds). Therefore, it is similar to the epeirogenically controlled transgression/regression episodes characteristic of the Canadian Cretaceous basins and some other Cretaceous basins (Jeletzky, 1978, pp. 33-36, figs. 10, 12).

\section{Late Jurassic Environments}

\section{Early Late Tithonian, Largely Mid-Neritic Phase}

Prior to the prolonged hiatus which separates the Barremian deep-water marine sediments from the lower upper Tithonian to middle Kimmeridgian beds (see Fig. 2 ), there is an interval of a relatively deeper but nevertheless shelf-depth deposition. This early late Tithonian interval (see Fig. 2 for its age limits) comprises Section 511-63-1, and Sections 511-63-2 to 511-63-4, including the core catcher.

The lithology of these cores does not differ much from that of the immediately overlying Barremian deepwater cores. However, the fairly common presence of Malayomaorica occidentalis n.sp. (its mode of occurrence ranges from scattered single shells to coquinoid interbeds), that of some thin-shelled oysters and other shelf-bound pelecypods, and that of rare belemnites of the genera Hastites and Hibolithes indicates a depositional environment that is inner to mid-neritic rather than outer neritic to upper bathyal for the fossiliferous intervals of the lower upper Tithonian cores. The rarity of belemnites and the absence of any shallow-water, thick-shelled pelecypods indicates that these sediments were deposited well below the wave base at depths ranging between 50 and 100 meters. The fairly common presence of ammonites also suggests at least a mid-neritic depositional environment.

The presence of entirely unfossiliferous intervals (e.g., the entire Section 511-63-4) in these sediments suggests that these particular intervals may have been deposited during a period of maximum deepening of the basin (i.e., in the outermost neritic or even perhaps the upper bathyal depth). The rarity of fish scales and bones is yet another feature that distinguishes the lower upper Tithonian sediments from the overlying deeper water Barremian sediments. This distinction probably reflects their relatively shallower depositional environment.

The depositional environment of the lower upper Tithonian argillaceous sediments was, generally speaking, a very low energy one, with relatively uncommon episodes of soft-sediment slumping and low-velocity turbidity currents. The fairly common presence of bottom-dwelling pelecypods, including some thin-shelled oysters, suggests that periods of euxinic environment at the bottom were alternating with a bottom environment that was at least moderately or nearly normally aerated. The apparent total absence of burrowing pelecypods suggests there is a reducing environment within the bottom sediment.

\section{Early Late Tithonian to Mid-Kimmeridgian Shallow-Water Phase}

The unfossiliferous black shales of Section 511-63-4 and the core catcher are underlain by mudstones which are, generally speaking, lithologically similar to the overlying lower upper Tithonian sediments. These partly sandy mudstones extend from the top of Section 51164-1 to about 511-65-2, $90 \mathrm{~cm}$; they are considerably more fossiliferous than those overlying sediments, and their macroinvertebrates include fairly common belemnites in addition to fairly numerous buchiid pelecypods, Inoceramus spp., and thick-shelled, shallow-water pelecypods (including oysters). This indicates an inner to perhaps mid neritic environment of deposition for this interval. Ammonites continue to be fairly common. This and the common presence of belemnites suggest normal or near normal salinity of the water. The mudstone becomes gradually sandier and sandier downward and the coquinoid mudstone interbeds consisting of various pelecypods become more and more common. This lithological change culminates in the appearance of numerous interbeds of presumably innermost neritic to littoral pelecypod coquina in sandy siltstone near to the base of this interval (at about 511-65-2, $90 \mathrm{~cm}$ ). This coquina includes some Belemnopsis in addition to thick-shelled Inoceramus, Malayomaorica occidentalis n.sp., and thinto thick-shelled oysters. This rather rapid lithological and faunal change heralds the end of the littoral to perhaps innermost neritic, partly delta-influenced episode in the Late Jurassic history of Hole 511 (see later and in Fig. 3). The gradual deepening of the sea reflected by the interval from $511-65-2,1-90 \mathrm{~cm}$ to $511-64-1$, inclusive, then culminated in the mid-neritic depositional environment of the early late Tithonian, represented by Sections 511-63-4 to 511-63-1, inclusive).

\section{Mid-Kimmeridgian Littoral to Brackish-Water Phase}

The intervals 511-65-2, 90-150 cm and from Sections 511-65-3 to 511-67-3 inclusive consist of a distinctly cyclical alternation of sandy to pure siltstone, fairly rich to very rich in fossils, with numerous $2-6-\mathrm{cm}$ or still thinner interbeds of pelecypod coquina. The fauna of these coquina interbeds consists predominantly of large Inoceramus ex gr. haasti-subhaasti, various thin- or thick-shelled oysters, and buchiids (almost exclusively Malayomaorica occidentalis $\mathrm{n}$. sp.). Some Meleagrinel$l a$-like shells occur locally. Hardly any ammonites and belemnites were seen in most of these coquina interbeds. The intervening, similarly thick interbeds of black, sandy to pure siltstone, moderately to richly fossiliferous, contain the same pelecypods, except that the oysters are either absent or rare for the most part. In contrast with the coquina interbeds, belemnites (Belemnopsis spp.) occur rarely to fairly commonly in these siltstone interbeds. However, the ammonites are all but absent in both the coquina and the siltstone interbeds.

The coquinas and sandy siltstones of the middle Kimmeridgian unit must have been deposited in a littoral to 
possibly innermost neritic environment of low to very low energy. This is indicated by the abundant presence of various thick-shelled, shallow-water pelecypods, including numerous to prevalent oysters, combined with the muddy to limy nature of the sediments, which include no pure, fine-grained sand and coarser clastics. The presence of belemnites in some interbeds also indicates a shallow-water environment, as does the almost total absence of ammonites, which are known to favor the outer to median shelf and upper bathyal environments.

The alternating sandy siltstone and coquina of the middle Kimmeridgian unit must have been deposited either within a shallow but well-protected (i.e., deeply indented) embayment of the coast (perhaps an estuary) or in a large lagoon, protected by an outer bar from the open sea. The frequent alternation of siltstones and some coquinas that contain belemnites but are largely or entirely lacking oysters with coquinas rich in oysters but lacking belemnites indicates that a normal or at least near-normal saline depositional environment was alternating equally frequently with a distinctly brackish depositional environment that must have been strongly influenced by an adjacent delta, possibly during unusually rainy periods.

In spite of their enrichment in organic carbon, the littoral to perhaps innermost neritic siltstones and coquinas of this middle Kimmeridgian unit must have been deposited in a normal to near-normal, aerated, bottom environment. The extreme richness of these sediments in thick-shelled, bottom-dwelling pelecypods militates against any suggestion of an oxygen-poor environment, let alone an anoxic one. However, the apparent absence of shallow- or deep-burrowing pelecypods and other mud-eating organisms (no worm burrows were seen) suggest that the bottom sediments themselves were deficient in oxygen. The mid-Kimmeridgian littoral to brackish-water beds represent another interruption of the prolonged period of anoxic depositional environment.

The major shoaling-up episode of mid-Kimmeridgian time is inserted between the two periods, in the early Kimmeridgian and in the mid-Kimmeridgian to early late Tithonian, respectively (Fig. 3), when the basin deepened considerably. The beginning of this shoalingup episode was relatively abrupt, geologically speaking, but it ended with a rather gradual deepening of the basin, as already noted.

The age of this major shallowing episode in Hole 511 appears to correspond closely (it may be slightly older, if the exclusively mid-Kimmeridgian age assigned the littoral to brackish-water episode is exact) to that of the interregional Nevadan orogeny, which affected much of the western Cordilleran belt of northern, central, and southern America (e.g., Arkell, 1956, pp. 552, 553, table 23 ; pp. $570,571,578$ ). This shallowing episode apparently was caused by an epeirogenic phase related to the Nevadan orogeny.

\section{Early Kimmeridgian and ?Oxfordian Mid-Neritic Phase}

The lowest core interval of Hole 511, beginning with Section 511-67-4 and ending with Section 511-70-5 (the bottom of the hole) consists of black, petroliferous mudstone (or siltstone), fairly rich to rich in belemnites (Belemnopsis spp.) throughout. Only a few ammonite fragments have been seen in this core interval. Thin-shelled buchiid (exclusively Jeletzkiella falklandensis) and ?oxytomid pelecypods occur scattered or form thin coquinoid interbeds at a few levels, but they are absent for the most part. No other pelecypods, or for that matter other macroinvertebrates, were seen. This combination of lithological and macropaleontological evidence indicates a low to very low energy, about mid-neritic ( 50 to ?150 $\mathrm{m}$ depth) depositional environment for this interval (Sections 511-70-1 and 511-70-2 were not studied because of lack of time). As already pointed out, the belemnites are known to be inhabitants of shelf sea and did not frequent even the outermost neritic regions with depth exceeding 100 to 150 meters.

The common occurrence of belemnites, which inhabit pelagic waters above the sea bottom, attests to the normally saline, presumably open marine character of the early Kimmeridgian and ?Oxfordian depositional environment.

The almost total absence of any bottom-dwelling organisms in the early Kimmeridgian and ?Oxfordian core interval, in combination with the organic-carbon-enriched character of the sediment and the presence of nectonic belemnites and ammonites, indicates anoxic bottom conditions throughout.

\section{APPENDIX}

Paleontological Descriptions and Taxonomic Notes on the Plates

Paleontological Descriptions

Malayomaorica occidentalis n.sp.

Synonymy. Malayomaorica cf. M. malayomaorica Jones and Plafker, 1977 , p. 847 , pl. 2, figs. $8,10-11,16-18$.

Holotype. Fragmentary left valve, USNM Cat. 339420 reproduced in Plate 1, Fig. 8.

Derivation of name. From the occurrence of this species in the Western Hemisphere, unlike all previously described Indo-Pacific representatives of the genus.

Material. Six definitively identifiable, late juvenile (e.g., Pl. 1, Fig. 13) to presumably adult (PI. 1, Fig. 8), more or less fragmentary specimens from Hole 511 (see Fig. 2 for further details). The very early juvenile shells ( $=$ spat) that are attached to the shell of Virgatosphinctes ex gr. densistriatus (Steuer)-denseplicatus (Waagen) reproduced in Pl. 1, Fig. 9 probably belong to this species also. Two figured specimens (Jones and Plafker, 1977, pl. 2, figs. 8, 10-11, 16-18) from Hole 330.

Diagnosis. Malayomaorica species that differs from other hitherto described representatives of the genus in (1) either a complete absence of radial ornament and reticulation or their replacement by faint radial striation; (2) considerably lesser width of ligamental plate of the left valve and the replacement of its anterior, characteristically prominent bulge by a slight swelling restricted to the anterior end of the plate; (3) absence of ligamental groove that is associated with the anterior bulge in $M$. malayomaorica and separates it from the ligamental plate proper; and (4) byssus ear pronouncedly bent toward the left valve and forming an angle of almost $90^{\circ}$ with the plane of junction of the valves.

Remarks. So far as it is possible to judge from the invariably fragmentary representatives presently available, the shape, proportions, and the adult size of Malayomaorica occidentalis $\mathrm{n}$.sp. fall within the known range of variation of these features in $M$. malayomaorica (Krumbeck, 1923) (compare Wandel, 1936, pp. 458, 459, pl. XVII, figs. 1-7; Jeletzky, 1963, pl. 21, figs. 1-2). However, the sculpture of the two species is different. As stressed by Jeletzky (1963, pp. 153, 154) the bulk of representatives of $M$. malayomaorica bear

closely spaced, fine, sharp and straight radial ribs intersecting more widely spaced concentric growth-lines (or growth ridges). 
In our material the radial ribs are generally speaking stronger developed on the left valve, where they tend to be about as strongly developed as the concentric growth lines (pl. 21, fig. $2 \mathrm{~B})$. In the right valve the concentric growth lines or growth ridges are generally speaking more strongly developed than the radial ribs (pl. 21, figs. $2 \mathrm{~A}, \mathrm{~F}$ ). The concentric growth-lines tend to be imbricated and lamellar in appearance in the best preserved specimens; they also tend to become markedly frilled and to form small, ill-defined tubercles and spines whenever intersected by the radial ribs (pl. 21, figs. $2 \mathrm{~A}, \mathrm{~B}, \mathrm{~F}$ ). The intersection of the radial and concentric elements of sculpture, which are about equally strongly developed, results in the markedly reticulate appearance of some parts of the shell's surface. In the specimens available, 1 was not able to observe clearly the intercalation of the second-order radial ribs with the first-order radial ribs observed by Krumbeck (1923, p. 67).

The strong variation in strength and character of the sculpture of M. malayomaorica has been stressed by all workers who have studied it (e.g., Krumbeck, 1923, p. 67; Wandel, 1936, pp. 458, 459, pl. XVII, figs. 1-7; Jeletzky, 1963, p. 153). Most of its population samples have been found to include more or less common specimens bearing the concentric ornament alone on parts or all of their shell. These specimens are associated with the strongly to distinctly radially ribbed and reticulated representatives which tend to prevail. However, according to Jeletzky (1963, p. 153), this marked variation

in strength and character of ornamentation from one specimen to another (or from one part of the shell to another within a single specimen) is at least partly related to the degree of abrasion of the shells concerned prior to or after their burial. This abrasion (e.g., in specimen shown in pl. 21, figs. 1A-G) was apparently facilitated by the restriction of ornamentation to the outer layers of the shell. The writer does not deny the strong variability of the ornamentation and the presence of specimens with obsolete sculpture. The sculpture of the specimen of $M$. malayomaorica shown in plate 21 , figs. $2 \mathrm{~A}, \mathrm{~B}, \mathrm{~F}$ is, nevertheless, assumed to be typical of the species. The specimens of M. malayomaorica figured by Boehm (1911, pl. 2, figs. 2-4 non 1) and the specimen figured by Marwick (1926, pl. 71 , fig. 10) are similarly strongly sculptured. The same is, finally, true of the herewith selected lectotype of the species.

Thus the strongly to markedly radially sculptured and reticulated representatives of $M$. malayomaorica, which are prevalent in all representative groups of its specimens derived from the same layers (i.e, population samples) that I have studied, differ markedly from all presently known representatives of $M$. occidentalis n.sp. in this respect. All specimens I have studied (e.g., Pl. 1, Figs. 8A-8C, 13B-C) and those studied by Jones and Plafker (1977, p. 847, pl. 2, figs. 16-18) are either entirely devoid of any radial ornament or exhibit only slight radial striae in addition to the much more strongly expressed concentric ribbing. The relatively rare presence of such specimens in the $M$. malayomaorica population samples does not appear to contradict the proposed specific separation of M. malayomaorica and $M$. occidentalis n.sp., in view of other morphological distinctions discussed below.

The sculpture of the still insufficiently known $M$. misolica (Krumbeck, 1934 , pp. 454,455 , pl. XV, figs. $10 \mathrm{a}, 10 \mathrm{~b}$ ) is even more unlike that of $M$. occidentalis n.sp. This sculpture is dominated by prominent, closely spaced radial ribs which are distinctly wavering and commonly form tubercles when crossing less prominent and much more widely spaced concentric ribs.

Another morphological distinction of $M$. occidentalis n.sp. from both $M$. malayomaorica and $M$. misolica is a much stronger deflection of the byssus ear of its right valve inward (i.e., toward the left valve).

As already pointed out by Jones and Plafker (1977, p. 847, pl. 2, fig. 8 ), the bysuss ear of $M$. occidentalis n.sp. is oriented almost perpendicularly to its left valve and forms an angle of almost $90^{\circ}$ with the junction plane of its valves. The byssus ear of $M$. malayomaorica is oriented obliquely in relation to the left valve and forms an angle of $20-40^{\circ}$ with the junction plane of its valves (Wandel, 1936, pl. XVII, figs. 1a, 1c, 4a, 4c, 11; Jeletzky, 1963, pl. 21, fig. 2F). The byssus ear of the only right valve of $M$. misolica known (Krumbeck, 1934, pl.
$\mathrm{XV}$, fig. 10a) appears to be even less deflected toward the left valve than is that of $M$. malayomaorica.

The third morphological distinction of $M$. occidentalis n.sp. from $M$. malayomaorica is an apparently complete absence of the ligamental groove that is associated with the anterior bulge in M. malayomaorica and separates the bulge from the ligamental plate proper (compare Pl. 1, Fig. 8E with Jeletzky, 1963, pl. 21, fig. 1F). The constancy of this distinction remains uncertain, as so far it has only been observed in the holotype of $M$. malayomaorica n.sp. It is not certain whether or not this groove is absent in the only left valve of $M$. occidentalis n.sp. figured by Jones and Plafker (1977, pl. 2, figs. 10, 11).

The much weaker development of the anterior bulge in the left ligamental plate of $M$. occidentalis n.sp. compared with that of $M$. malayomaorica appears to be a feature that is correlative with a much stronger inward deflection of its byssus ear (compare Jeletzky, 1963, pl. 21, fig. 2F with Jones and Plafker, 1977, pl. 2, fig. 8). The same may also be true of the absence of the ligamental groove in the left valve of our species.

The sum total of these morphological distinctions is judged to be ample for the full specific separation of $M$. occidentalis n.sp. from $M$. malayomaorica and M. misolica, considering its occurrence in another hemisphere, almost half of the circumference of the globe away from the other two species.

Age and correlation. See the main text and Figs. 2-3.

\section{Taxonomic Notes on the Plates}

All specimens are reproduced actual size, unless otherwise indicated.

\section{Plate 1}

Figure 1. Aconeceras? (s.s.) sp. indet., USNM Cat. 339413, from Sample 511-37-3, 50-51 cm, in the upper Aptian beds. A. Lateral view of whorl fragment; B. Same view as in A, but $\times 2$ to show clearly the serrated keel (see arrow) and the virtually smooth flank. Note the Cerithium-like gastropods surrounding the ammonite fragment.

Figure 2. Australiceras? sp. indet., USNM Cat. 339414, from Sample 511-58-1, 137-138 cm, in the upper Aptian beds. Lateral view.

Figure 3. Generically indeterminate perisphinctid ammonite, USNM Cat. 339419, from Sample 511-63-1, 82-84 cm, in the upper part of the Malayomaorica occidentalis beds from the upper lower Tithonian section (=upper Kimmeridgian).

Figure 4. Indeterminate ammonite, USNM Cat. 339415, from Sample $511-70-3,22-23 \mathrm{~cm}$, in the Lower Kimmeridgian and ?Oxfordian Belemnopsis $\mathrm{cf}$. keari beds. A. Lateral view; B. Lateral view, $\times 2$.

Figure 5. ?Torquatisphinctes sp. indet., USNM Cat. 339416, from Sample 511-64-4, 16-17 cm, in the lower part of the Malayomaorica occidentalis beds, associated with its lower belemnite fauna from the upper part of the lower Tithonian (=mid-Kimmeridgian). A. Lateral view; $B$. Ventral view.

Figure 6. Belemnopsis n.sp. aff. spathi Stevens, 1965, USNM Cat. 339417 , from Sample 511-69-1, 106-108 cm, in the lower part of the Malayomaorica occidentalis beds containing the lower belemnite fauna from the upper part of the lower lower Tithonian (=middle Kimmeridgian). A. Ventral view; B. Right lateral view (venter left); C. Dorsal view; D. Cross-section of alveolar end with the lower part of alveolus preserved (venter below); E. Cross-section of apical end (venter below).

Figure 7. Cheloniceras (Epicheloniceras) sp. indet., USNM Cat. 339418 , from Sample 511-57-4, 65-66 cm, in the upper Aptian beds. A. Approximate ventral view of almost flattened venter and left flank; B. Same view as in A but $\times 2$ to show clearly the diagnostic forward bends of secondaries in the mid-venter and the bifurcation of primaries at the ventro-lateral nodes.

Figure 8. Malayomaorica occidentalis n.sp., holotype, USNM Cat. 339420, from Sample 511-65-3, 15-18 cm, in the lower part of the $M$. occidentalis beds, associated with the lower belemnite fauna from the upper part of the lower lower Tithonian (=middle Kimmeridgian). A. Left (or outside) view of the partially preserved left valve (lower part destroyed by the drill). The beak part of the valve is uplifted so that its cut-off middle part is concealed; B. Left lateral view; C. Dorsal (or outside) view of the beak part; D. Inside view; E. Inside view, $\times 3$. Note the strongly attenuated appearance of the ligamental plate 
and the almost complete absence of an anterior bulge in comparison with $M$. malayomaorica (compare Jeletzky, 1963, pl. 21, figs. $1 \mathrm{~F}, 2 \mathrm{~F}$ ).

Figure 9. Virgatosphinctes ex gr. densistriatus (Steuer)-denseplicatus Waagen), USNM Cat. 339421, from Sample 511-63-3, 49-50 cm, in the upper part of the Malayomaorica occidentalis beds, associated with the upper belemnite fauna from the upper lower Tithonian (=upper Kimmeridgian). Lateral view of fragment with completely flattened outer and almost undeformed inner whorls.

Figure 10. Jeletzkiella falklandensis Jones and Plafker, 1977, USNM Cat. 339422, from Sample 511-68-1, 101-103 cm, in the lower Kimmeridgian and ?Oxfordian Belemnopsis cf. keari beds. Right valve. A. Right (or outside) view; B. Posterior view $\times 2$; C. Same view as in A but $\times 4$ to show clearly the detail of the Buchia-like ornament; D. Inside view of the hinge part, $\times 6$ to show structural detail of the ligmental plate, byssus notch, and byssus ear. Most of the bladelike part of the byssus ear is broken off; E. Dorsal (or outside) view of the hinge part, $\times 6$ to show the somewhat oblique orientation of the preserved part of the byssus ear, resulting in its anteriorly closed Buchia-like appearance.

Figure 11. ?Arctotis (probably a new genus) n.sp. A, superficially resembling $A$. intermedia Bodylevsky (i.e, shells marked 1 to 3 in B) and ?Meleagrinella sp. indet. (i.e, the shell marked 4 in B), from Sample 511-60-2, 53-58 cm, in the lower Aptian and ?uppermost Barremian Aucellina ex aff. radiatostriata beds. A. General view of the split core; B. Same view as in A but $\times 3$. The three best preserved valves of ?Arctotis n.sp. A are marked 1 to 3 (USNM Cat. 339423, 339457, and 339458 respectively) to facilitate a comparison with their other views in Figs. C-E. A valve of ?Meleagrinella sp. indet. is marked 4 (USNM Cat. 339459); C. Cross-sections of the three ?Arctotis n.sp. A valves shown in $\mathrm{B}$ (numbered as they are there), $\times 3$; D. Oblique dorsal (or outside) view of the hinge margin of the right valve no. 3 demonstrating a deeply grooved structure of the underside of byssus ear, $\times 6$.

Figure 12. Jeletzkiella falklandensis Jones and Plafker, 1977, USNM Cat. 339424, from Sample 511-68-1, 127-128 cm, in the lower Kimmderidgian and ?Oxfordian Belemnopsis cf. keari beds. Left valve. A. left (or outside) view; B. Anterior view; C. Right (or inside) view; D. Dorsal (or outside) view of hinge margin, $\times 3$; E. Posterior view of the beak part, $\times 6 ; \mathrm{F}$. View of the ligamental plate, $\times 4$. Note its strong morphological similarity with that of Malayomaorica occidentalis n.sp. (see Pl. 1, Fig. 8E).

Figure 13. Malayomaorica occidentalis n.sp., USNM Cat. 339425, from Sample 511-63-1, 146-147 cm in the upper part of the $M$. occidentalis Beds, associated with the upper belemnite fauna from the upper lower Tithonian (=upper Kimmeridgian). A half-grown, considerably deformed left valve preserved in the same piece of core with other indeterminate pteriid pelecypods (see Fig. 13A). A. Split piece of core consisting of coquinoid shale. The left valve of $M$. occidentalis n.sp. is marked 1 , and the best preserved right valve of an indeterminate pteriid is marked 2; B. Dorsal view of the left valve of $M$. occidentalis $\mathrm{n} . \mathrm{sp}$., $\times 4$; C. Left (or outside) view of the same valve, $\times 3$. This specimen of $M$. occidentalis n.sp. is important in documenting the early Tithonian age of the lower part of Section 511-63-1, which otherwise yielded only a less diagnostic, generically indeterminate perisphinctid ammonite (see Pl. 1, Fig. 3).

Figure 14. Aucellina radiatostriata Bonarelli, 1921, s.l., USNM Cat. 339426, from Sample 511-51-1, 148-149 cm in the Albian $A$. radiatostriata beds. Half-grown right valve of an extreme form almost devoid of the radial ornament. A. Right (or outside) view; B. Same view as in $\mathrm{A}$ but $\times 4$ to demonstrate an almost complete absence of radial ornament; concentric ornament is likewise very weak. The byssus ear is characteristically long and incurved, and its margins exhibit feeble tubercles forming a ctenolium. Except for these features, diagnostic of the genus Aucellina Pompeckj, 1901, this shell would be hard to distinguish from Jeletzkiella. It does not seem to be a new Aucellina species associated and connected by transitional forms with typical representatives of $A$. radiatostriata Bonarelli, 1921 (e.g., Pl. 3 , Figs. 3-4, 6, 11); C. Dorsal (or outside) view of the hinge margin, $\times 4$, showing the long, strongly incurved byssus ear diagnostic of Aucellina.

Figure 15. ?Arctotis (probably a new genus) n.sp. B, superficially similar to A. intermedia Bodylevsky, USNM Cat. 339427, from Sample 511-59-4, 86-91 cm, in the lower Aptian and ?uppermost Barremian Aucellina ex aff. radiatostriata beds. A well-preserved and complete right valve. A. Right (or outside) view; B. Same view as in A but $\times 4$ to show clearly details of radial ornament, which abruptly changes from pronounced and sharp-topped like ?Meleagrinella sp. indet. (see Pl. 1, Fig. 11B, specimen 4), to subdued and round-topped in the early growth stage. Distinct concentric riblets appear at the same time. Note the long and incurved byssus ear, apparently morphologically transitional to that of Aucellina (compare Pl. 1, Fig. 14); C. Dorsal (or outside) view of hinge margin, $\times 4 ; 15 \mathrm{D}$. Ventral (or inside) view of the hinge margin, $\times 4$.

Figure 16. Inoceramus sp. indet. This fragment, USNM Cat. 339428 , from Sample 511-70-4, 136-137 cm, in the lower Kimmeridgian and ?Oxfordian Belemnopsis cf. keari beds, resembles closely I. ex gr. galoi Boehm in its ribbing habit but is indeterminate in its fragmentary state of preservation.

\section{Plate 2}

Figure 1. ?Hastites sp. indet., USNM Cat. 339429, from Sample 511-64-6, 17-18 cm, from the lower part of Malayomaorica occidentalis n.sp. beds carrying the lower belemnite fauna of the upper part of the lower lower Tithonian (=mid-Kimmeridgian). A. Ventral view. The short medioventral alveolar furrow just below the Actinocamaxlike weathered oral end is not a medioventral canal, such as occurs in Belemnopsis, as it is not accompanied by a splitting surface; B. Right lateral view. Venter is on the right; C. Dorsal view; D. Cross-section of the adapical part of the fragment, a few $\mathrm{mm}$ above its obliquely ground-off part, $\times 2$; venter is below; E. Cross-section of the Actinocamax-like weathered oral end, $\times 2$; venter is below.

Figure 2. Belemnopsis cf. keari Stevens, 1965, USNM Cat. 339430, from Sample 511-70-3, 84-85 cm, in the lower Kimmeridgian and ?Oxfordian Belemnopsis cf. keari beds. Alveolar fragment of an adult representative of the species. A. Ventral view; B. Right lateral view (venter left); C. Dorsal view; D. Cross-section of oral end (venter below).

Figure 3. Belemnopsis cf. moluccana (Boehm, 1907), USNM Cat. 339431, from Sample 511-64-3, 147-148 cm, in the uppermost part of the lower Malayomaorica occidentalis n.sp. beds, from the middle Kimmeridgian-upper lower Tithonian boundary beds. Fragment of stem region of a late juvenile specimen. A. Ventral view; B. Right lateral view (venter left); C. Dorsal view; D. Cross-section of oral end (venter below), $\times 2$; E. Cross-section of apical end (venter below), $\times 2$.

Figure 4. Belemnopsis cf. stolleyi Stevens, 1965, USNM Cat. 339432, from Sample 511-66-2, 91-92 cm, in the lower part of the $M a$ layomaorica occidentalis n.sp. beds, carrying the lower belemnite fauna, from the upper part of the lower lower Tithonian (=mid-Kimmeridgian). Fragment of the stem and apical regions of a half grown specimen. A. Ventral view. B. Right lateral view (venter left). Note typically developed double lateral lines; C. Dorsal view; D. Cross-section of oral end (venter below); E. Cross-section of apical end (venter below).

Figure 5. Belemnopsis cf. stolleyi Stevens, 1965, USNM Cat. 339433 , from Sample 511-66-4, $46 \mathrm{~cm}$, in the lower part of the $\mathrm{Ma}$ layomaorica occidentalis $\mathrm{n} . \mathrm{sp}$. beds carrying the lower belemnite fauna, from the upper part of the lower lower Tithonian (=mid-Kimmeridgian). Fragment of the stem and apical regions of a late juvenile specimen. A. Ventral view; B. Right lateral view (venter left); C. Dorsal view; D. Cross-section of the middle part of fragment (at the break clearly visible in Figs. 5A-5C). Venter is below; E. Cross-section of the apical end (venter below).

Figure 6. Hibolithes sp. indet. A, USNM Cat. 339434, from Sample 511-59-4, 69-76 cm, in the lower Aptian and ?uppermost Barremian Aucellina ex aff. radiatostriata beds. Fragment of the oral part of the stem region of an ?adult representative. A. Ventral view; B. Left lateral view (venter right); C. Dorsal view; D. Cross-section of oral end (venter above); E. Cross-section of apical end (venter below).

Figure 7. Belemnopsis cf. moluccana (Boehm, 1907), USNM Cat. 339435 , from Sample $511-67-1,44-46 \mathrm{~cm}$, in the lower part of the Malayomaorica occidentalis $\mathrm{n}$.sp. beds containing the lower belemnite fauna, from the upper part of the lower lower Tithonian (=midKimmeridgian) beds. Fragment of the stem region of a late juvenile representative. A. Ventral view; B. Right lateral view (venter left); C. Dorsal view; D. Cross-section of oral end, $\times 2$ (venter below); E. Cross-section within the apical third of the fragment (i.e., at the fracture clearly visible in Figs. 7B and 7C), $\times 2$. Venter is below.

Figure 8. Belemnopsis n.sp. indet. juven., USNM Cat. 339436, from Sample $511-67-5,50-52 \mathrm{~cm}$, in the lower Kimmeridgian and ?Oxfordian Belemnopsis cf. keari Beds. Fragment of the stem region 
and the complete apical region of a juvenile specimen resembling $B$. moluccana in the development of its medioventral canal but considerably more slender, subconically shaped, and less depressed in cross-section. A. Ventral view; B. Right lateral view (venter left); C. Dorsal view; D. Cross-section of oral end, $\times 2$ (venter below); E. Cross-section of apical end, $\times 2$ (venter below).

Figure 9. Belemnopsis cf. keari Stevens, 1965, USNM Cat. 339437, from Sample 511-67-5, $91 \mathrm{~cm}$, in the Kimmeridgian and ?Oxfordian Belemnopsis cf. keari beds. Fragment of a half-grown representative consisting of the apicalmost part of the stem and the completely preserved apical region. A. Ventral view; B. Left lateral view (venter right); C. Dorsal view; D. Left lateral view (venter right), $\times 2$. Introduced to show better lateral longitudinal furrows and lines. Note indistinct double lateral lines in the distinct adventral furrow, short dorso-lateral apical groove (an abnormal feature in Belemnopsis) and what seems to be median and addorsal lateral grooves; E. Crosssection of the oral end (venter below); F. Cross-section of the apical end (venter below).

Figure 10. Belemnopsis n.sp. aff. spathi Stevens, 1965, USNM Cat. 339438, from Sample 511-68-2, 55-56 cm, in the Lower Kimmeridgian and ?Oxfordian Belemnopsis cf. keari beds. A late juvenile representative that lacks only the most oral part of the alveolar region and the apical half of the apical region but is somewhat deformed and weathered. A. Ventral view; B. Left lateral view (venter right); C. Right lateral view (venter left); D. Cross-section of the apical end (venter below), $\times 2$; E. Same view as in C. but $\times 3$ to show clearly the somewhat weathered double lateral lines on the lower half of the flank; F. Same view as in B but $\times 3$ to show clearly the typically developed double lateral lines restricted to the posterior two-fifths of the flank. The view is slightly oblique so that the medioventral canal is visible in the extreme right.

Figure 11. Hibolithes sp. indet. B, USNM Cat. 339439, from Sample $511-62-5,76-82 \mathrm{~cm}$, in the Barremian beds. Fragment of the alveolar region of an adult specimen presumed to be conspecific with the apical fragment reproduced in Fig. 12. This form differs from $H$. sp. indet. A reproduced in Fig. 6 in its relatively sturdier proportions, equidimensional to depressed cross-section and stronger exfoliation of the alveolar region. A. Ventral view; B. Left lateral view (venter right); C. Dorsal view; D. Cross-section of the oral end (venter below); E. Cross-section of apical end (venter below).

Figure 12. Hibolithes sp. indet. B., USNM Cat. 339440, from Sample 511-62-5, 76-82 cm, in the Barremian beds. Fragment of the apical region of an adult guard presumed to be conspecific with the fragment reproduced in Fig. 11. A. Ventral view; B. Left lateral view (venter right); C. Dorsal view; D. Cross-section just below the groundoff oral end (i.e, at the fracture visible in B and C). Venter is below; $\mathrm{E}$. Cross-section of the apical end (venter below).

Figure 13. Belemnopsis cf. keari Stevens, 1965, USNM Cat. 339441, from Sample 511-67-4, 9-10 cm, in the lower Kimmeridgian and ? Oxfordian Belemnopsis cf. keari beds. Fragment of the apical region of an adult guard comparable in size to the alveolar fragment reproduced in Fig. 2. A. Ventral view; B. Left lateral view (venter right); C. Dorsal view; D. Cross-section of the oral end (venter below); E. Cross-section of the apical end (venter below).

Figure 14. Belemnopsis aff. B. orientalis (Waagen, 1873), USNM Cat. 339442, from Sample 511-68-1, 11-12 cm, in the lower Kimmeridgian and ?Oxfordian Belemnopsis cf. keari beds. A. Ventral view; B. Left lateral view (venter right); C. Dorsal view; D. Cross-section of the alveolar end (venter below); E. Cross-section of the apical end (venter below).

Figure 15. Belemnopsis cf. keari Stevens, 1965, USNM Cat. 339443 , from Sample 511-67-2, 95-96 cm in the middle-lower Kimmeridgian boundary beds between the upper and lower parts of the Malayomaorica occidentalis beds (i.e., the topmost bed containing the lower belemnite fauna). Stem fragment of a slender, presumably halfgrown representative. A. Ventral view; B. Left lateral view (venter right); C. Dorsal view; D. Lateral view as in B but $\times 2$ to show more clearly the double lateral lines confined to the most apical preserved part of the flank and two longitudinal furrows confined to its remainder; E. Cross-section of the oral end (venter below), $\times 2$; F. Crosssection of the apical end (venter below), $\times 2$.

\section{Plate 3}

Figure 1. Aucellina radiatostriata Bonarelli, 1921, s.1., USNM Cat. 339444, from Sample 511-52-7, $43-45 \mathrm{~cm}$, in the Albian A. radia- tostriata beds. Fairly large, presumably adult right valve of the extremely pronouncedly sculptured variant of the species (compare with A. caucasica Abich, 1851 from the Aptian rocks of Arctic Canada, reproduced in Fig. 15). A. Right (or outside) view. B. Same view as in A but $\times 4$ to show clearly the diagnostic ctenolium on the inner margin of byssus ear.

Figure 2. ?Arctotis (presumably a new genus) n.sp. B., USNM Cat. 339445, from Sample 511-59-1, 9-11 cm, in the lower Aptian and ?uppermost Barremian Aucellina ex aff. radiatostriata beds. Right valve of what is believed to be the extremely feebly sculptured variant of the form reproduced in Pl. 1, Fig. 15). A. Right (or outside) view; B. Same view as in A but $\times 3$ to show clearly the concentric growth lines, very fine but more pronounced in comparison with the radial ornament; C. Same view as in A but $\times 4$ and in strong lateral light to show clearly the subdued radial ornament and byssus ear.

Figure 3. Aucellina radiatostriata Bonarelli, 1921 s.l., USNM Cat. 339446 , from Sample $511-52-5,116-121 \mathrm{~cm}$, in the Albian $A$. radiatostriata beds. Medium-sized, presumably half-grown right valve of a variant characterized by a subdued, delicate ornament. The unusually widely spaced and sparse radial ribs first weaken and then almost disappear in the later growth stages while the concentric growth lines gradually become more prominent, imbricated structures. This variant is morphologically transitional between those reproduced in Pl. 1, Fig. 14 and Pl. 3, Fig. 1). A. Right (or outside) view; B. Same view as in A but $\times 3$ to show clearly details of ornament and its ontogenetic development.

Figure 4. Aucellina radiatostriata Bonarelli, 1921 s.l., USNM Cat. 339447 , from Sample 511-52-5, 116-121 cm in the Albian $A$. radiatostriata beds. Fairly small, presumably late juvenile left valve of the same almost smooth variant as the right valve reproduced in Pl. 1, Fig. 14. A. Left (or outside) view; B. Anterior view; C. Dorsal view of the beak part; D. Same view as in A but $\times 4$ to demonstrate an almost complete absence of radial ornament (reduced to some radial striae) and the strongly subdued nature of the concentric growth lines; E. Left (or inside) view, $\times 4$ to show the underside of the beak and the morphology of the ligamental plate.

Figure 5. ?Meleagrinella sp. indet., USNM Cat. 339448, from Sample 511-59-3, 134-138 cm, in the lower Aptian and ?uppermost Barremian Aucellina ex aff. radiatostriata beds. Outside views of a small, presumably late juvenile to half-grown right valve. A. Right (or outside) view; B. Same view as in A but $\times 4$ to show clearly the ornamentation and the angular appearance of the posterior ear. The byssus ear is broken off.

Figure 6. Aucellina radiatostriata Bonarelli, 1921 s.l., USNM Cat. 339449 , from Sample 511-55-5, 108-109 cm, in the Albian $A$. radiatostriata beds. Small, presumably late juvenile to half-grown left valve of the same morphologically median variant as the right valve reproduced in Fig. 3. A. Left (or outside) view; B. Dorsal view of the beak part; C. Anterior view; D. Same view as in A but $\times 4$ to show clearly the delicate and subdued radial and concentric ornament, which matches closely that of the right valve reproduced in Fig. 3B; E. Same view as in $\mathrm{C}$ but $\times 4$ to show clearly the degree of coiling, prominent arching, and gradual strengthening of the concentric ornament during the ontogeny; F. The same view as in B but $\times 4$ to show clearly the markedly convex cross-section of the valve.

Figure 7. Aucellina radiatostriata Bonarelli, 1921 s.1., USNM Cat. 339450 , from Sample 511-50-1, 124-128 cm, in the Albian A. radiatostriata beds. Fairly large but fragmentary, presumably adult, right valve with unusually well preserved inner side of byssus ear, byssus slit, and posterior wing. A. Left (or inside) view; B. Same view as in A but $\times 3$ to show clearly the morphology of the underside of byssus ear, etc. Judging by the impressions of radial ribs on the inner surface of the shell, this specimen belongs to the same extremely strongly sculptured variant as the right valve reproduced in Fig. 1.

Figure 8. Aucellina radiatostriata Bonarelli, 1921 s.1., USNM Cat. 339451 , from Sample 511-52-5, 116-121 cm, in the Albian A. radiatostriata beds. Medium-sized, presumably half-grown (compare with the left valve reproduced in Fig. 11) left valve with a moderately prominent ornament, which appears to be morphologically transitional between those of the morphologically median variant reproduced in Fig. $6 \mathrm{D}$ and the morphologically extreme variant reproduced in Fig. 1A, B. This valve is extremely strongly coiled for the species. A. Left (or outside) view. Direction of shot approximately perpendicular to the plane of contact of the valves; B. Anterior view, showing clearly the Gryphea-like mode of coiling; C. Left (or outside) view. The beak part 
of the valve uplifed to show its strong tapering toward the beak proper; D. The same view as in A but $\times 3$ to show clearly the gradual strengthening of concentric growth lines during the later growth stages combined with an equally gradual decline of the radial ribbing; E. Somewhat oblique anterior view $\times 3$ to show clearly the ontogenetic changes of ornament on this flank; F. The same view as $C$ but $\times 3$ to show clearly the much greater prominence of the radial ornament and the much weaker development of concentric growth lines on the early growth stages as compared with the later growth stages (compare D).

Figure 9, ?Meleagrinella sp. indet., USNM Cat. 339452, from Sample 511-59-3, 134-138 cm, in the lower Aptian and ?uppermost Barremian Aucellina ex aff. radiatostriata beds. Inside views of a small, presumably late juvenile to half-grown right valve. A. Left (or inside) view; B. The same view as in A but $\times 4$ to display the characteristically long and bladelike byssus ear and the narrow byssus slit. The characteristic radial ornament (compare Fig. 10) is clearly imprinted on the inner surface of the shell; $C$. Essentially the same view as in $A$ and $B$ but $\times 6$ and with the hinge margin tilted toward the camera so as to display the characteristic bulges of the ligamental plate and the incurved, round-bottomed furrow crossing the underside of the byssus ear.

Figure 10. ?Meleagrinella $\mathrm{sp}$. indet. Same sample, rock unit and age as for the specimen reproduced in Fig. 9. Left (or outside) view of two fragmentary left valves exhibiting characteristic radial ornament, $\times 3$.

Figure 11. Aucellina radiatostriata Bonarelli, 1921 s.1., USNM Cat. 339453, from Sample 511-50-3, 137-141 cm, in the Albian A. radiatostriata beds. Fairly large, presumably half-grown left valve of a broad but high-arched, feebly sculptured variant that is most similar in its sculptural habit to the left valve displayed in Fig. 4. A. Left (or outside) view; B. A somewhat oblique anterior view; C. Dorsal view of the beak part.

Figure 12. Aucellina ex aff. radiatostriata Bonarelli, 1921 s.1., USNM Cat. 339454, from Sample 511-58,CC (12-14 cm) in the lower Aptian and ?uppermost Barremian Aucellina ex aff. radiatostriata beds. Fairly small, presumably either late juvenile or half-grown left valve of Aucellina form that appears to differ from the younger $A$. radiatostriata in the considerably thinner and broader proportions of its shell and a considerably shorter, more swollen and less incurved left beak (compare Figs. 6, 8,11). This form resembles somewhat the New Zealand A. euglypha Woods (e.g., Speden, 1977, figs. 7-9) and the Boreal $A$. aptiensis Pompeckj (e.g., Jeletzky, 1964, pl. XVIII, figs. 4, 6; pl. XX, figs. 3-4, 6). However, it is left specifically undetermined pending further study of the material available. A. Left (or outside) view; B. Same view as in A but $\times 3$ to show clearly the delicate radial and concentric ornament that retains the same appearance throughout; C. Dorsal view of the beak part, $\times 3$ to show the thin and broad proportions of the valve.

Figure 13. Aucellina radiatostriata Bonarelli, 1921 s.l., USNM Cat. 339455, from Sample 511-53-2, 148-150 cm, in the Albian $A$. radiatostriata beds. Fairly small, presumably late juvenile or halfgrown, fragmentary and deformed right valve with well-preserved byssus ear, posterior wing, and early ornament. The strength of the ornament is transitional between that of the right valves reproduced in Figs. 1 and 3. A. Right (or outside) view; B. Same view as in A but $\times 5$ to show clearly the structural detail.

Figure 14. Aucellina radiatostriata Bonarelli, 1921 s.1., USNM Cat. 339456, from Sample 511-52-5, 116-121 cm, in the Albian $A$. radiatostriata beds. SEM photomicrographs of juvenile right valve of a variant that matches closely that reproduced in Fig. 13. A. Right (or outside) view, $\times 14$. The incurved shape of byssus ear, its ctenolium, and a pronounced bulge of the ligamental plate situated at the base of the ear are clearly visible; B. Oblique left (or inside) view of the byssus ear and ligamental plate, $\times 14$. Note the grooved appearance of the underside of the byssus ear.

Figure 15. Aucellina caucasica (Abich, 1851). GSC loc. 86717, GSC Cat. No. 69148, from the Aptian Rat River Formation, N.W.T. (Arctic Red River sheet, Stony Creek, $67^{\circ} 21^{\prime} \mathrm{N}, 135^{\circ} 15^{\prime} \mathrm{W}$. Coll. Shell Oil Co., 1959, Field No. KG-512-162-N59.) Internal cast of a fairly large, presumably adult right valve. Introduced for comparison with the extremely prominently sculptured variant of $A$. radiatostriata s.l. exemplified by Fig. 1. A. Right (or outside) view. Note the considerably greater width of byssus slit and relatively more narrow byssus ear as compared with those of all figured representatives of $A$. radiatostriata s.1. B. The beak part of the specimen, $\times 4$ to show its structural detail.

Figure 16. ?Arctotis (presumably a new genus) n.sp. B., USNM Cat. 339457, from Sample 511-59-1, 9-11 cm, in the lower Aptian and ?uppermost Barremian Aucellina ex aff. radiatostriata beds. Left valve of the same variant of the form as the right valve reproduced in Fig. 2. A. Left (or outside) view of the valve. Two other poorly preserved valves of what appears to be the same form are also visible on the slab; B. Same view as in A but $\times 4$ to show the structural detail better. The other upward concave valve partly concealed beneath the left valve appears to be its right counterpart. The ornament of the left valve consists of barely perceptible concentric growth lines and radial striae.

\section{ACKNOWLEDGMENTS}

All photographs in this paper were taken by J. White, Geological Survey of Canada, except for SEM photomicrographs reproduced in Pl. 3, Figs. 14A, B, which were taken by D. A. Walker, Geological Survey of Canada.

\section{REFERENCES}

Abich, H., 1851. Verzeichniss einer Sammlung von Versteinerungen von Daghestan. Z. Deutsch. Geol. Ges., 3.

Arkell, W. J., 1956. Jurassic Geology of the World: Edinburgh (Oliver and Boyd).

Arkell, W. J., Kummel, B., and Wright, C. W., 1957. Mesozoic Ammonoidea. In Moore, R. C. (Gen. Ed.), Treatise on Invertebrate Paleontology, Part L, Mollusca 4, Cephalopoda, Ammonoidea: Lawrence, Kansas (Geol. Soc. Am. and University of Kansas Press), pp. L80-L472.

Bodylevsky, V. I., 1960. Novy pozdneyurskii predstavitel' avikulopectenid [A new Late Jurassic representative of aviculopectenids]. Novye vidy drevnikh rastenii $i$ bespozvonochnyh SSSR [New species of ancient plants and animals of the U.S.S.R.], Part 2: Moscow, (Gosgeoltekhizdat), 44-45. (In Russian)

Boehm, G., 1911. Grenzschichten zwischen Jura und Kreide von Kawhia (Nordinsel Neuzeelands). N. Jahrb. Mineral. Geol. Palaeontol., 1:1-24.

Bonarelli, G., and Nagera, J. J., 1921. Observaciones Geologicas en las Immediaciones del Lago San Martin (Territorio de Santa Crux). Dir. Gral. Minas, Buenos Aires Bol. 27B.

Casey, R., 1954. Falciferella, a new genus of Gault ammonites, with a review of the family Aconeceratidae in the British Cretaceous. Proc. Geol. Assoc. (London), 65:262-277.

1961. The stratigraphical paleontology of the Lower Greensand. Palaeontology, 3:487-621.

1961-1966. The Ammonoidea of the Lower Greensand: London (Paleontogr. Soc.).

Challinor, A. B., 1979. The succession of Belemnopsis in the Heterian stratotype, Kawhia Harbour, New Zealand. N.Z.J. Geol. Geophys., 22(1):105-123.

Cox, L. R., 1953. Lower Cretaceous Gastropoda, Lamellibranchiata and Annelida from Alexander I Land (Falkland Islands Dependencies): Falkland Islands Dependencies Survey, Scientific Reports, No. 4.

Cox, L. R., 1969. Family Oxytomidae. In Moore, R. C. (General Ed.), Treatise on Invertebrate Paleontology, Part N, Volume 1 (of 3), Mollusca 6, Bivalvia: Lawrence, Kansas (Geol. Soc. AM. and University of Kansas Press), pp. N1-N489.

Day, R. W., 1969. The Lower Cretaceous of the Great Artesian Basin. In Campbell, K. S. W. (Ed.), Stratigraphy and Paleontology: Essays in Honour of Dorothy Hill: Canberra (A.N.U. Press), pp. 140-173.

1974. Aptian Ammonites from the Eromanga and Surat Basins, Queensland. Publ. Geol. Surv. Queensl. No. 360, Paleontol. Paper No. 34

Favre, F., 1908. Die Ammoniten der unteren Kreide Patagoniens. $N$. Jahrb. Mineral. Geol. Paleontol., Beil. Bd., 25:601-647.

Feruglio, E., 1936. Paleontographia Patagonica. I. Lago Argentino. 1. Tithoniano e Infracretaceo della regione del Lago Argentino. Memorie Inst. Geol. Padova 11.

Indans, J., 1954. Eine Ammonitenfauna aus dem Untertiton der Argentinischen Kordillere in Sued-Mendoza. Palaeontographica, Abt. A, 105(3-6):96-132. 
Jeletzky, J. A., 1963. Malayomaorica gen. nov. (Family Aviculopectinidae) from the Indo-Pacific Upper Jurassic; with comments on related forms. Palaeontology, 6(1):148-160.

1964. Illustrations of Canadian Fossils. Lower Cretaceous Marine Index Fossils of the Sedimentary Basins of Western and Arctic Canada. Geol. Surv. Pap. (Geol. Surv. Can.), 64-11. 1968. Macrofossil Zones of the Marine Cretaceous of the Western Interior of Canada and Their Correlation with the Zones and Stages of Europe and the Western Interior of the United States. Geol. Surv. Pap. (Geol. Surv. Can.), 67-72.

1978. Causes of Cretaceous Oscillations of Sea Level in Western and Arctic Canada and Some General Geotectonic Implications. Geol. Surv. Pap. (Geol. Surv Can.), 77-18.

Jeletzky, J. A., and Tipper, H. W., 1968. Upper Jurassic and Cretaceous Rocks of Taseko Lakes Map-Area and Their Bearing on the Geological History of Southwestern British Columbia. Geol. Surv. Pap. (Geol. Surv. Can.), 67-54.

Jones, D. L., and Plafker, G., 1977. Mesozoic megafossils from DSDP Hole 327A and Site 330 on the Eastern Falkland Plateau. In Barker, P. F., Dalziel, I. W. D., et al., Init. Repts. DSDP, 36: Washington (U.S. Govt. Printing Office), 845-855.

Kauffman, E. G., 1973. Cretaceous Bivalvia. In Hallam, A. (Ed.) Atlas of Paleobiogeography: Amsterdam (Elsevier), pp. 353-383.

Klinger, H. C., and Kennedy, W. J., 1977. Cretaceous faunas from Zululand, South Africa and Southern Mozambique. The Aptian Ancyloceratidae (Ammonoidea). Ann. S. Afr. Mus., 73(9):215-359.

Krumbeck, L., 1923. Zur Kenntnis des Juras der Insel Timor, sowie des Aucellen-Horizontes von Seran und Buru. Palaontologie von Timor, 12: Stuttgart (Schweitzerbart'sche), 1-120.

1934. Die Aucellen des Malms von Misol. Neues Jahrb. Mineral. Geol. Palaeontol., Beil. Bd., 71B:422-469.

Leanza, H. A., 1980. The lower and middle Tithonian ammonite fauna from Cerro Lotena, Province of Neuquen, Argentina. Zitteliana, Abh. Bayer. Staatssammlung Palaontol. Hist. Geol., 5:3-49.

Ludbrook, N. H., 1966. Cretaceous Biostratigraphy of the Great Artesian Basin in South Australia. South Aust. Geol. Surv. Bull. No. 40.

, 1978. Australia. In Moullade, M., and Nairn, A. E. M. (Eds.), The Phanerozoic Geology of the World II. The Mesozoic, A: Amsterdam (Elsevier), pp. 209-244.

Ludwig, W. J., Krasheninnikov, V. A., Basov, I. A, Bayer, U., Bloemendal, J., Bornhold, B., Ciesielski, P., Goldstein, E. H., Robert, C., Salloway, J. C., Usher, J. L., Dick, H. von der, Weaver, F. M., and Wise, S. W., Jr., 1980. Tertiary and Cretaceous paleoenvironments in the Southwest Atlantic Ocean: Preliminary results of Deep Sea Drilling Project Leg 71. Geol. Soc. Am. Bull., 91(No. 11): $655-664$.

Macellari, C. E., 1979. La presencia del genero Aucellina (Bivalvia, Cretacico) en la formacion Hits XIX (Tierra del Fuego, Argentina). Ameghiniana, 16(1-2):143-172.

Marwick, J., 1926. Myalinidae from the Jurassic of New Zealand, a new genus and new species. Trans. Proc. N. Z. Inst., 56(new issue): 304-306.

Pavlow, A. P., 1907. Enchainement des Aucelles et Aucellines du Crétacé russe. Nouv. Mem. Soc. Imp. Naturalistes, Moscow, Vol. 17.

Pompeckj, J. P., 1901. Ueber Aucellen und Aucellenaehnliche Formen. N. Jahrb. Mineral. Geol. Palaeontol., Beil. Bd., 14:319-368.

Spath, L. F., 1927. Revision of the Jurassic Cephalopod Fauna of Kachh (Cutch). Mem. Geol. Surv. India, N. S., Vol. 9, Mem. No. 2.
Speden, I. G., 1977. Taitai Series (Early Cretaceous) and the elimination of the Mokoiwian Stage. N. Z. J. Geol. Geophys., 20:537-562.

Speden, I. G., and Keyes, I. W., 1981. Illustrations of New Zealand Fossils. Inf. Ser. N.Z. Dept. Sci. Ind. Res., No. 150.

Stevens, G. R. ,1963a. The systematic status of Oppel's specimens of Belemnites gerardi. Palaeontology, 6(4):690-698.

1963b. Designation of a lectotype for the nominal species Belemnopsis alfurica (Boehm) 1907 (Cephalopoda, Dibranchiata). Trans. R. Soc. N.Z. Geol., 2(6):101-104.

1965a. The Jurassic and Cretaceous belemnites of New Zealand and a review of the Jurassic and Cretaceous belemnites of the Indo-Pacific Region. N.Z. Geol. Surv. Palaeontol. Bull., 36:1-236.

1965b. A new belemnite from the Upper Jurassic of Indonesia. Palaeontology, 7(4):621-629.

1978. Paleontology. In Suggate, R. P., Stevens, G. R. and Te Punga, M. T. (Eds.), The Geology of New Zealand (2 vols.): Wellington (Govt. Printer), 1:215-228 (Jurassic); 2:351-366 (Cretaceous).

Stevens, G. R., and Speden, I. G., 1978. New Zealand. In Moullade, M., and Nairn, A. E. M. (Eds.), The Phanerozoic Geology of the World II. The Mesozoic, A: Amsterdam (Elsevier), pp. 251-320.

Stolley, E., 1929. Ueber Ostindische Jura-Belemniten. Palaeontologie von Timor: Stuttgart (Schweizerbart'sche), 16:91-213.

Terekhova, G. P., 1972. O nekotorykh razvernutykh nizhnemelovykh ammonitakh severo-vostoka SSSR [Some uncoiled Lower Cretaceous ammonites of the northeastern part of the U.S.S.R.]. Severo-Vostochnoe Territorial'noye Orderna Trudovogo Krasnogo Znameni Geologicheskoye Upravlenie, Materialy po Geologii i Poleznym Iskopaemym Severo-Vostoka SSSR, No. 20:200-210. (In Russian)

Verestchagin, V. N., 1977. Melovaya Systema Dal'nego Vostoka [Cretaceous System of the Far Eastern Part of the USSR]. Tr. Vses. Ordena Lenina Nauchno-Issled. Geol. Inst., N. S., Vol. 242. 208 pages.

Verestchagin, V. N., Kinassov, V. P., Paraketsov, K. V., and Terekhova, G. P., 1965. Polevoi Atlas Melovoi Fauny Severo-vostoka SSSR [Field Atlas of the Cretaceous Fauna of the Northeastern part of the U.S.S.R.]: Magadan (Gossudarstvennyi Proizvodstvennyi Geologicheskii Komitet RSFSR, Severo-Vostochnoye Geologicheskoye Upravlenie). (In Russian)

Wandel, G., 1936. Beitrage zur Kenntnis der jurassischen Molluskenfauna von Misol. Ost-Celebes, Buton, Seran and Jamdena. Neues. Jahrb. Mineral. Geol. Palaeontol., Beil. Bd., 75B:447-526.

Wilkens, O., 1947. Palaeontologische und Geologische Ergebnisse der Reise von Kohl-Larsen (1928-29) nach Sued-Georgien. Abh. Senckenb. Naturforsch. Ges., No. 474.

Willey, L. E., 1973. Belemnites from south-eastern Alexander Island: II. The occurrence of the family Belemnopseidae in the Upper Jurassic and Lower Cretaceous. Br. Antarct. Surv. Bull., No. 36: 33-59.

Zakharov, V. A., 1966. Pozdneyurskie i Rannemelovye Dvustvorchatye Molluski Severa Sibiri i Usloviia Ikh Sustchestvovaniia (Otriad Anisomyaria) [Late Jurassic and Early Cretaceous Bivalved Mollusks of Northern Siberia and the Paleoenvironmental Conditions of Their Existence (Order Anisomyaria)]. Akad. Nauk SSSR, Sibirskoye Otdelenie, Institut Geologii i Geofiziki: Moscow (Nauka). ,1981. Buchiids and biostratigraphy of the Boreal Upper Jurassic and the Neocomian. Akad. Nauk SSSR, Sibirskoye Otdelenie, Inst. Geol. i Geofiz. Trudy, No. 458:56-57. 


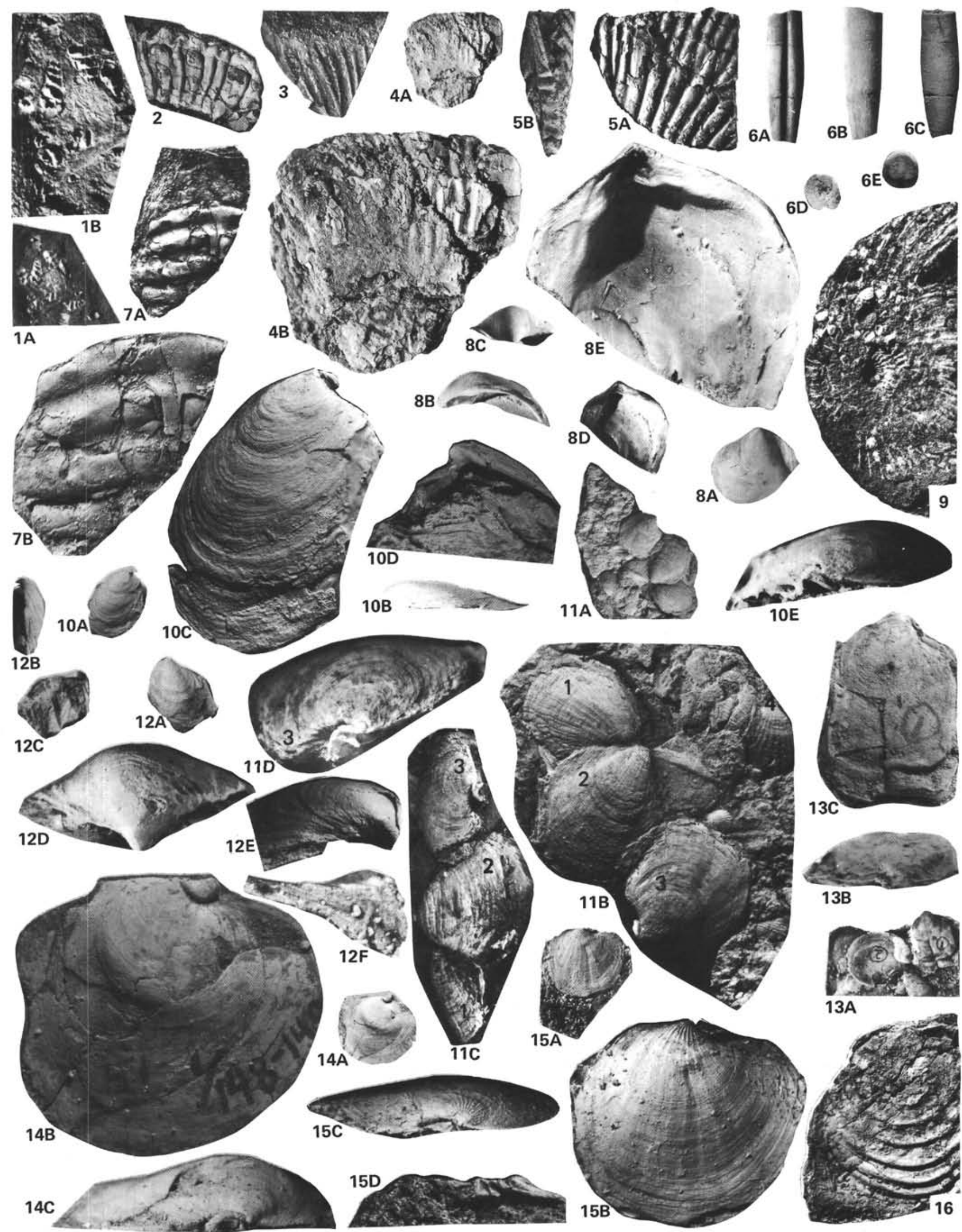

Plate 1. (For explanations, see the Taxonomic Notes on the Plates). 


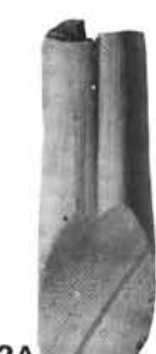

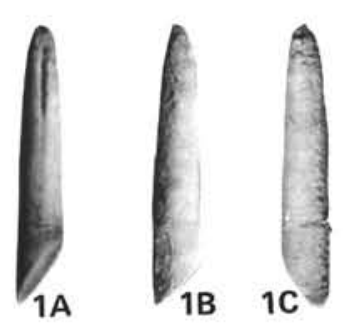
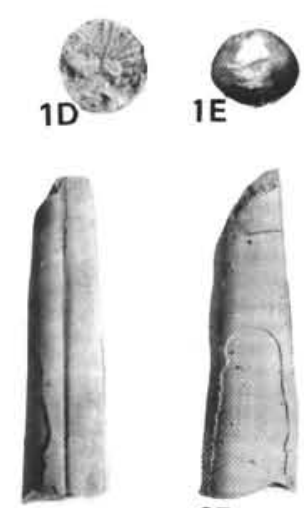

$6 A$
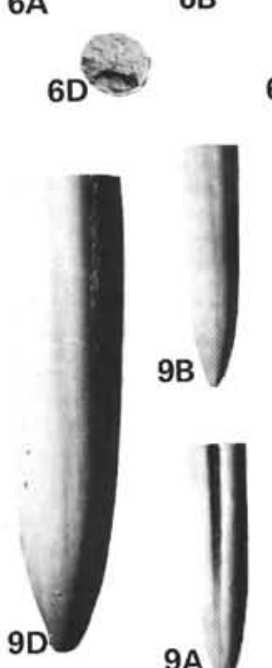

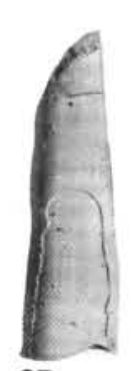

6B
$2 A$

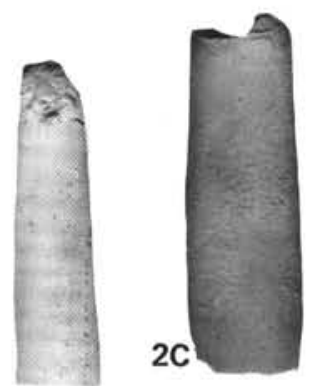

6C

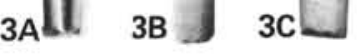

2B
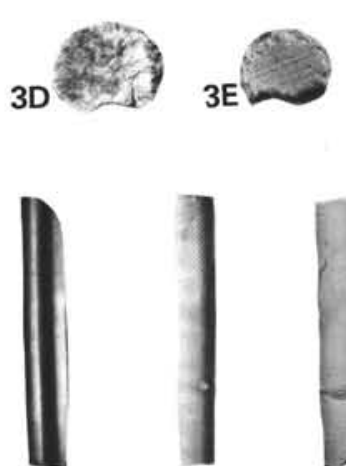

$7 A$
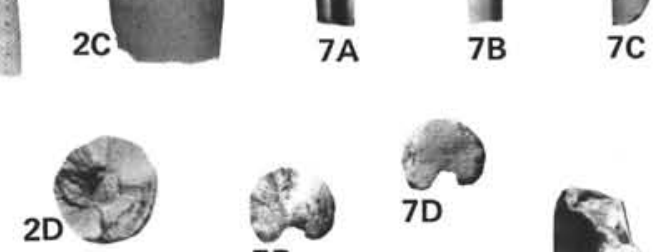

$7 \mathrm{E}$
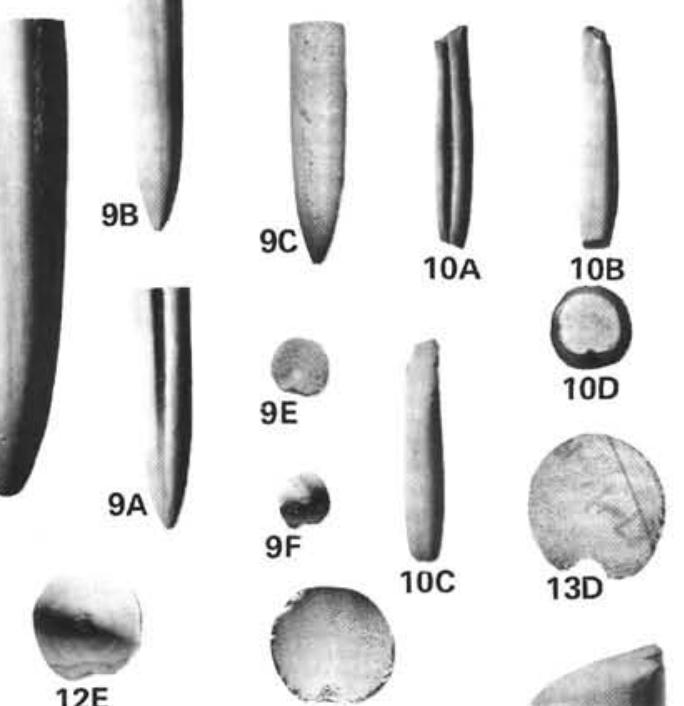

$9 A$
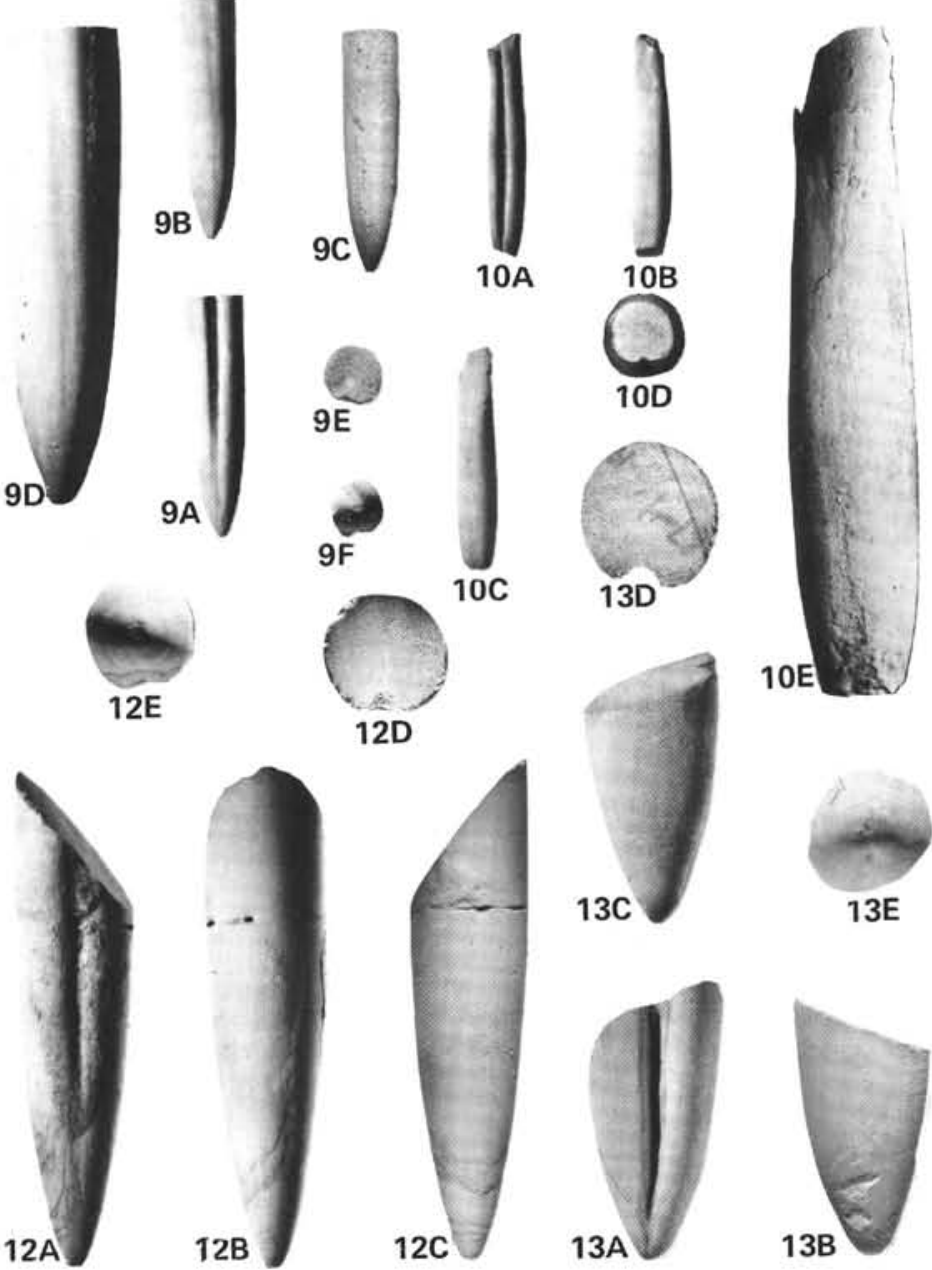

$10 \mathrm{E}$
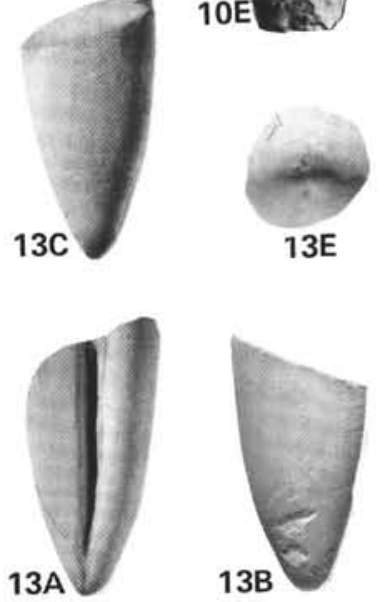
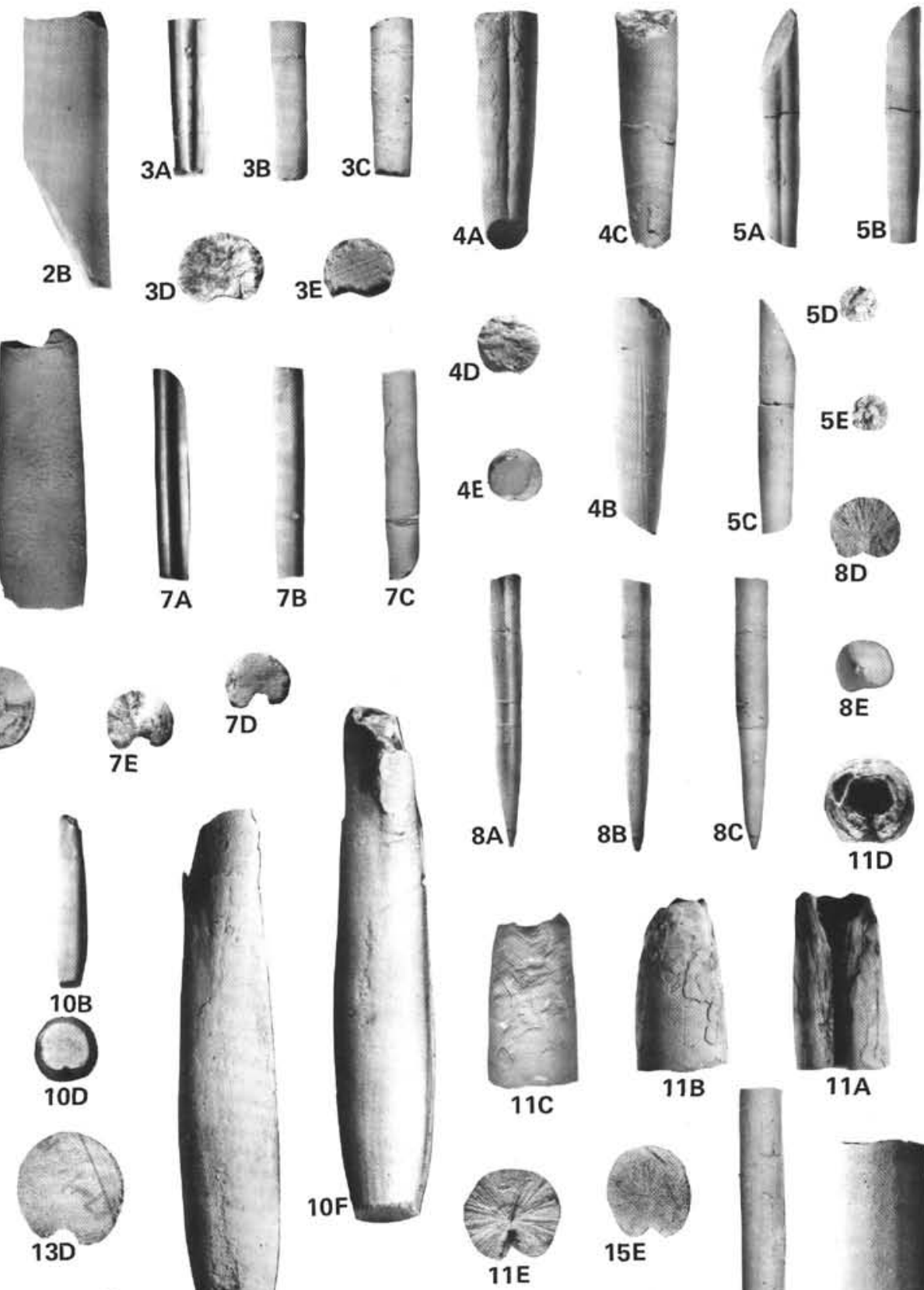

15E
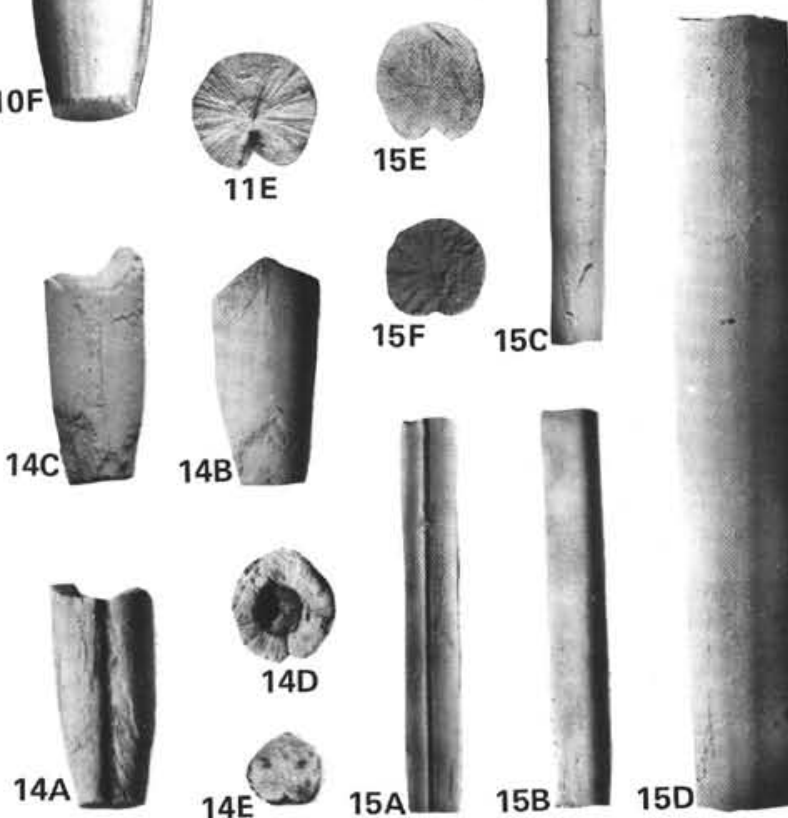
$14 \mathrm{E}$ 15.

Plate 2. (For explanations, see the Taxonomic Notes on the Plates). 


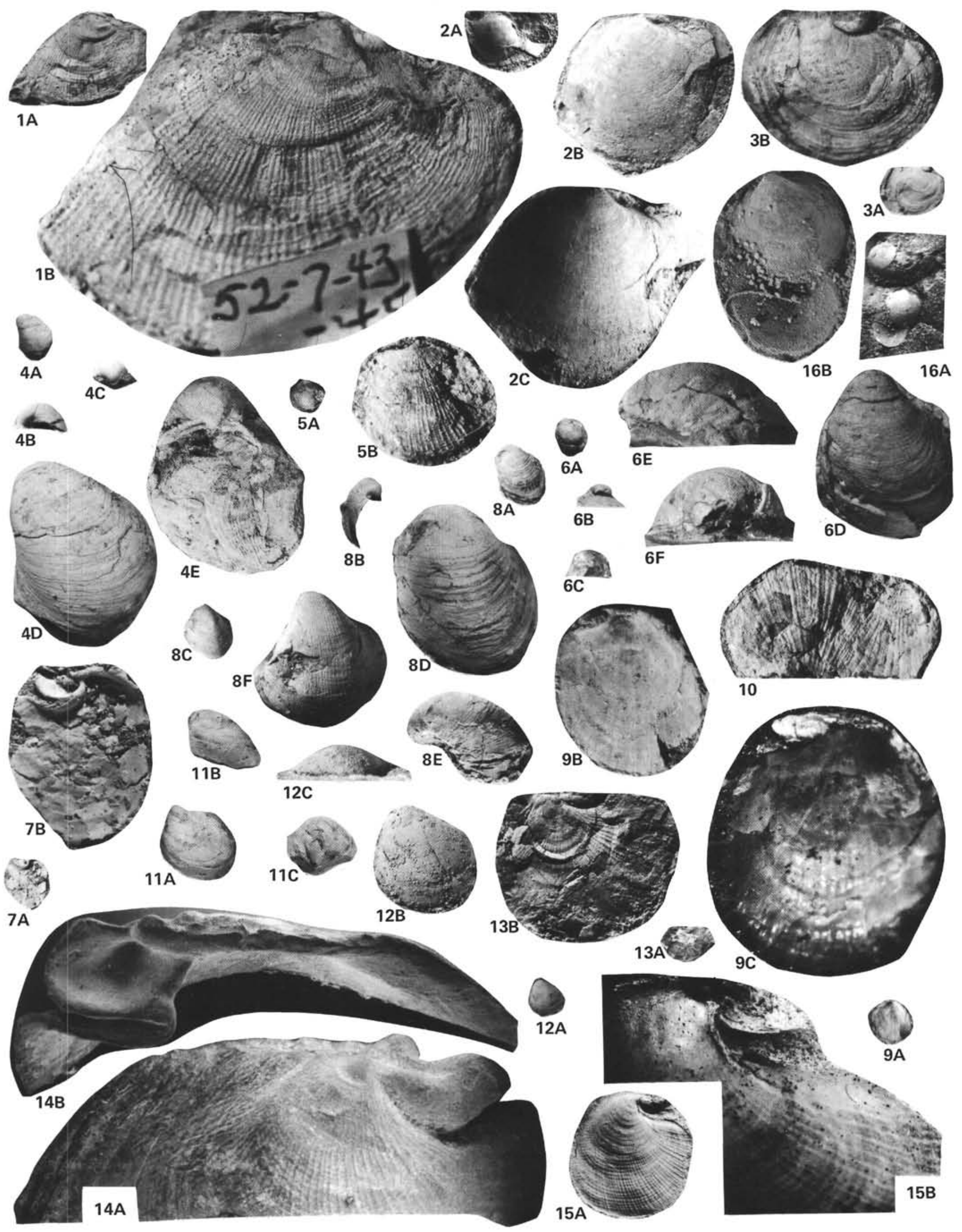

Plate 3. (For explanations, see the Taxonomic Notes on the Plates). 